https://doi.org/10.11646/phytotaxa.324.1.1

\title{
Toward a monograph of non-marine Ulvophyceae using an integrative approach (Molecular phylogeny and systematics of terrestrial Ulvophyceae II.)
}

\author{
TATYANA DARIENKO ${ }^{1} \&$ THOMAS PRÖSCHOLD ${ }^{2}$ \\ ${ }^{1}$ University of Göttingen, Experimental Phycology and Culture Collection of Algae, Nikolausberger Weg 18, D-37073 Göttingen, Ger- \\ many, and Kholodny Institute of Botany, National Academy of Science, Tereschenkivska Str. 2, Kyiv 01601, Ukraine \\ ${ }^{2}$ University of Innsbruck, Research Institute for Limnology, Mondseestr. 9, A-5310 Mondsee, Austria \\ Corresponding author:Thomas Pröschold,E-mail:Thomas.Proeschold@uibk.ac.at
}

\begin{abstract}
Phylogenetic analyses of SSU rDNA sequences have shown that coccoid and filamentous green algae are distributed among all classes of the Chlorophyta. One of these classes, the Ulvophyceae, mostly contains marine seaweeds and microalgae. However, new studies have shown that there are filamentous and sarcinoid freshwater and terrestrial species (including symbionts in lichens) among the Ulvophyceae, but very little is known about these species. Ultrastructural studies of some of them have confirmed that the flagellar apparatus of zoospores (counterclockwise basal body orientation) is typical for the Ulvophyceae. In addition to ultrastructural features, the presence of a "Codiolum"-stage is characteristic of some members of this algal class. We studied more than 50 strains of freshwater and terrestrial ulvophycean microalgae obtained from the different public culture collection and our own isolates using an integrative approach. Three independent lineages of the Ulvophyceae containing terrestrial species were revealed by these methods. Unexpectedly each of these lineages contained several isolates that morphologically developed a high degree of phenotypic plasticity, and included hidden phylogenetic diversity that let us to the description of several new genera and species.
\end{abstract}

Keywords: CBC concept, ITS-2 Barcode, molecular phylogeny, species delimitation, Ulvophyceae

\section{Introduction}

Traditionally, most freshwater and terrestrial green algae belonged to the classes Chlorophyceae and Trebouxiophyceae (Ettl \& Gärtner 1995). In contrast the class Ulvophyceae is dominated by species that are distributed in marine habitats. Phylogenetic analyses of terrestrial green algae using SSU rDNA sequences have shown that many filamentous and sarcinoid algae that were previously assigned to the Chlorophyceae are members of the Ulvophyceae. For examples, the genera Dilabifilum (Thüs et al. 2011), Planophila, Pseudendocloniopsis (Friedl \& O‘Kelly 2002), Pseudendoclonium, Ulothrix zonata, Gloeotilopsis (Friedl 1996), Desmochloris (Darienko et al. 2009, Watanabe et al. 2001), Hazenia (Skaloud et al. 2013a), Helicodictyon (Watanabe et al. 2001, Watanabe 2002), and Ignatius (Watanabe \& Nakayama 2007) are ulvophytes isolated from terrestrial or freshwater habitats. However, the species concepts within these genera remain unresolved because of the phenotypic plasticity as demonstrated for Desmochloris mollenhaueri Darienko, Friedl et Pröschold (Darienko et al. 2009). Many ulvophycean taxa have been described but never investigated using modern molecular techniques (e.g. Borzi 1883, Nichols \& Bold 1965, Biebel 1968, Tupa 1974). Using an integrative approach in the first study of 'Molecular phylogeny and systematics of terrestrial Ulvophyceae', the species of the genus Desmochloris could be differentiated based on morphology, phylogeny, and molecular signatures using the secondary structures of ITS-1 and ITS-2. Originally the type species of Desmochloris, D. halophila (Guillard, Bold et MacEntree) Watanabe, Kuroda et Maiwa, was described as Chlorosarcinopsis, a genus belonging to the Chlorophyceae, which is common in terrestrial habitats (Guillard et al. 1975). As shown for D. mollenhaueri, terrestrial ulvophytes change morphology depending on different salinities (Darienko et al. 2009), resulting in their difficult identification using traditional keys. To resolve this problem, robust molecular phylogenetic reconstruction and DNA barcoding can help to identify the microorganisms at generic and species levels and reveal hidden diversities among the Ulvophyceae. 
The aim of the second contribution is to resolve the taxonomic status and phylogenetic position of the genera abovementioned. Despite the different generic assignment of those taxa, most species have a similar morphology (cell packages with a tendency to form branched pseudofilaments or filaments) and show a high phenotypic plasticity, making it very difficult to identify them at the species level. Some of these taxa were originally described as members of the genera Pseudendoclonium Wille, Pseudopleurococcus Snow emend. Vischer, or Dilabifilum Tschermak-Woess, which are similar in morphology but are separated from each other by the absence of certain morphological features. For example, the first two genera differ only by the absence of zoospores and the exclusive occurrence in terrestrial habitats by Pseudopleurococcus. Dilabifilum was separated by the formation of Microthamnion-like branching filaments, which do not appear in Pseudendoclonium. Considering the evaluation of these features, several authors considered these characters differently, resulting in different generic assignments of these species (see, e.g., Printz 1964, Bourrelly 1966, 1990, Ettl \& Gärtner 1995). Other genera were described exclusively based on ecological preferences. For example, Geitler (1942) described the genus Rhexinema solely based on its growth in neuston.

To solve these taxonomic problems, we used the integrative approach introduced by Pröschold \& Leilaert (2007) to the abovementioned genera. The detailed procedure has been described by Darienko et al. (2016), and it is based on phylogenetic analyses of SSU and ITS rDNA sequences in combination with the morphology and life cycle of the investigated strains. According to the phylogeny of SSU rDNA sequences, terrestrial and freshwater ulvophytes belong to five independent lineages called Chlorocystis-, Pirula-, Trichosarcina-, Ignatius-, and Trentepohlia-clades sensu Pröschold \& Leliaert (2007). The taxonomic status of some genera and their abovementioned species must be resolved and is the topic of this contribution. As many publications have shown, the phylogeny of green algae can be clearly resolved using a concatenated data set of SSU and ITS rDNA sequences. Among monophyletic lineages (= genera), the species concept is based on the ITS-2/CBC approach described by Demchenko et al. (2012) and Darienko et al (2015, 2016). In this approach, the internal transcribed spacer region 2 (ITS-2) has been used to delimitate organisms at the species level. Coleman (2000) has shown that strains of the volvocalean green algae (Chlorophyceae), which are able to mate representing a Z(ygote)-clade or biological species, have identical conserved regions of ITS-2. In contrast, if two species differ in at least one compensatory base change (CBC; i.e., A-U to G-C), they cannot mate. Therefore, ITS-2 can be used for species delimitation and has been used in many studies of the green algae.

The aims of this study are as follows: (1) to provide a robust phylogeny of non-marine ulvophytes, which will then be the basis of (2) species delimitation among the abovementioned genera; (3) to distinguish the species by application of the ITS-2/CBC approach; (4) to identify necessary taxonomic changes, including descriptions of new genera and species; (5) to generalize the applied approach to identify the hidden diversity among this morphologically variable group of green algae.

\section{Material \& Methods}

\section{Algal material and culture conditions}

In this study, more than 50 strains with different affiliations were obtained from public and working culture collections. Detailed information about their habitat and origin is presented in Table S1. All of the algal strains were cultivated in modified Bold ìs Basal Medium (3N-BBM+V; medium 26a in Schlösser 1997), Basal and Desmidiacean medium (ES, MiEB12; media 1 and 7 in Schlösser 1994) and in media with different salinities (SWES, and 1/2SWES; media 5, 6 in Schlösser 1994, respectively) under standard conditions (light:dark cycle of $14: 10 \mathrm{hrs}$ at $18^{\circ} \mathrm{C}$ and $50 \mu \mathrm{mol}$ photons $/ \mathrm{m}^{2} \mathrm{~s}^{1}$ provided by daylight fluorescent tubes, Osram L36W/954 Lumilux de lux daylight, Munich, Germany). For species identification, the identification keys of Ettl \& Gärtner (1995, 2014), Printz (1964), Tupa (1974), and Starmach (1972) were used and the morphology of the strains was compared with the original species descriptions. For the light microscope investigations, an Olympus BX-60 microscope was used (Olympus, Tokyo, Japan), and the micrographs were obtained with a ProgRes C14 plus camera using the ProgRes Capture Pro imaging system (version 2.9.0.1; both from Jenoptik, Jena, Germany).

\section{DNA extraction, PCR and sequencing}

Genomic DNA was extracted from most of the strains using the DNeasy Plant Mini Kit (Qiagen, Hilden, Germany) following the instructions that were provided by the manufacturer. The SSU and ITS rDNA were amplified by PCR using the Taq PCR MasterMix Kit (Qiagen, Hilden, Germany) with primers EAF3 and ITS055R (Marin et al. 2003). For some strains for which the PCR amplifications and several nested PCR variants were not successful, the following 
approach was applied. The DNA was extracted using the CTAB method (Friedl 1996) with the following modifications. The lysate of broken cells (broken in liquid nitrogen using a tissue lyser) in extraction buffer B $(1.4 \mathrm{M} \mathrm{NaCl}, 100 \mathrm{mM}$ Tris, $20 \mathrm{mM} \mathrm{Na}{ }_{2}$ EDTA, $\mathrm{pH}$ 8.0) was mixed with $200 \mu 110 \% \mathrm{CTAB}\left(\mathrm{w} / \mathrm{v}\right.$ in buffer B) and incubated at $70^{\circ} \mathrm{C}$ for $1 \mathrm{~h}$. This mixture was then shaken with phenol/chloroform/isoamylalcohol (No. A156.1, Roth, Germany) for 10 min. The DNA extraction then followed the description published by Friedl (1996).

The SSU and ITS rDNA were amplified in two separate PCR reactions using the primer combinations EAF3/ N1400R and N920F/ITS055R (Marin et al. 2003). Both PCR products have a $500 \mathrm{bp}$ of sequence overlap for proofing that no chimeras have been created or sequenced. The sequences of the strains SAG 467-1 and CCMP 2158 were obtained by cloning according to the procedure described by Hallmann et al. (2013).

All PCR products were purified and sequenced as described by Demchenko et al. (2012). All of the sequences are available in the EMBL, GenBank and DDBJ sequence databases under the accession numbers provided in Fig. 1.

\section{Alignment and phylogenetic analyses}

The SSU rDNA sequences of all the strains were aligned according to their secondary structures using the structure of Ulothrix zonata (SAG 38.86; see Fig. S1) as a template. The introns if present (numbers and positions of present introns are given in Table S1) were excluded from the datasets. The ITS-1 and ITS-2 sequences of all strains were folded according to the protocol described in detail in Darienko et al. (2015). The ITS-2 secondary structures of the type species of each genus are summarized in Figs S2. The alignments were separated into three datasets: (i) the SSU alignment containing 106 taxa with $1770 \mathrm{bp}$ of representatives of the Ulvophyceae using the Oltmannsiellopsis-clade as outgroup, (ii) concatenated dataset of 29 SSU and ITS rDNA sequences (2554 bp) of the Ulvales sensu Mattox and Stewart, and (iii) concatenated dataset of 33 SSU and ITS rDNA sequences (2355 bp) of the Ulotrichales sensu Mattox and Stewart.

The evolutionary models that fit best for all of the datasets (concatenated and separated according to their genes) were calculated using the program Modeltest 3.7 (Posada 2008). The best models were then selected using the Akaike Information Criterion (Akaike 1974). The settings of the best models are given in the figure legends. For the phylogenetic analyses the following methods were used: distance, maximum parsimony, maximum likelihood, and Bayesian inference as described in Darienko et al. (2015). The phylogenetic calculations were conducted using the programs PAUP version 4.0b10 (Swofford 2002), RAxML version 7.0.3 (Stamatakis 2006), MrBayes version 3.1 (Huelsenbeck \& Ronquist 2001, Ronquist \& Huelsenbeck 2003), and PHASE package 2.0 (Jow et al. 2002, Higgs et al. 2003, Hudelot et al. 2003, Gibson et al. 2005, Telford et al. 2005).

\section{ITS-2 secondary structures and ITS-2/CBC approach}

For phylogenetic analyses and comparisons of ITS-2 sequences it is crucial to obtain an accurate model of the secondary structure. The commonly used computer programs (mfold; Zuker 2003 and RNAfold; Lorenz et al. 2011) use the thermodynamical model (minimal energy) to fold RNA sequences. CONTRAfold (Do et al. 2006), another program used a stochastic approach for the RNA folding. Both methods require complete and unambiguous ITS-2 sequences with their flanking regions of the $5.8 \mathrm{~S}$ and LSU sequences. For accurate analyses described in the following chapters we used all sequences of the datasets analyzed for Figs 2 and 3 and compared them with those already published to prove if ITS-2 is suitable as phylogenetic marker and as barcode marker. Those sequences have been folded using the three programs mentioned above with the three constraints described as follows: (1) the last 25 bases of the 5.8S rRNA and the first 25 of the LSU rRNA must bind and form the 5.8S/LSU stem, (2) the pyrimidine/pyrimidine mismatch (the first RNA processing site) in Helix II after the 5-7th base pair has to be present in the structure, and (3) the second RNA processing site, the GGU motif characteristic for green algae, has to be at the 5' site in Helix III (for details about the processing sites and constraints; see Coleman 2003, Cote et al. 2002). The ITS-2 secondary structures of each type species were visualized using the program VARNA (Darty et al. 2009) and presented in the supplemental material (Figs S2).

For the usage of ITS-2 as DNA Barcode it is absolutely necessary to obtain ITS sequences free of ambiguities with the flanking regions of 5.8S and LSU rDNA to avoid analyzing pseudogenes. Only then it is possible to fold a unique secondary structure model of ITS- 2 with the constraints mentioned above. For species identification among the genera, the ITS-2/CBC approach was applied following exactly the procedure that is described in Darienko et al. (2015) for Coccomyxa. 


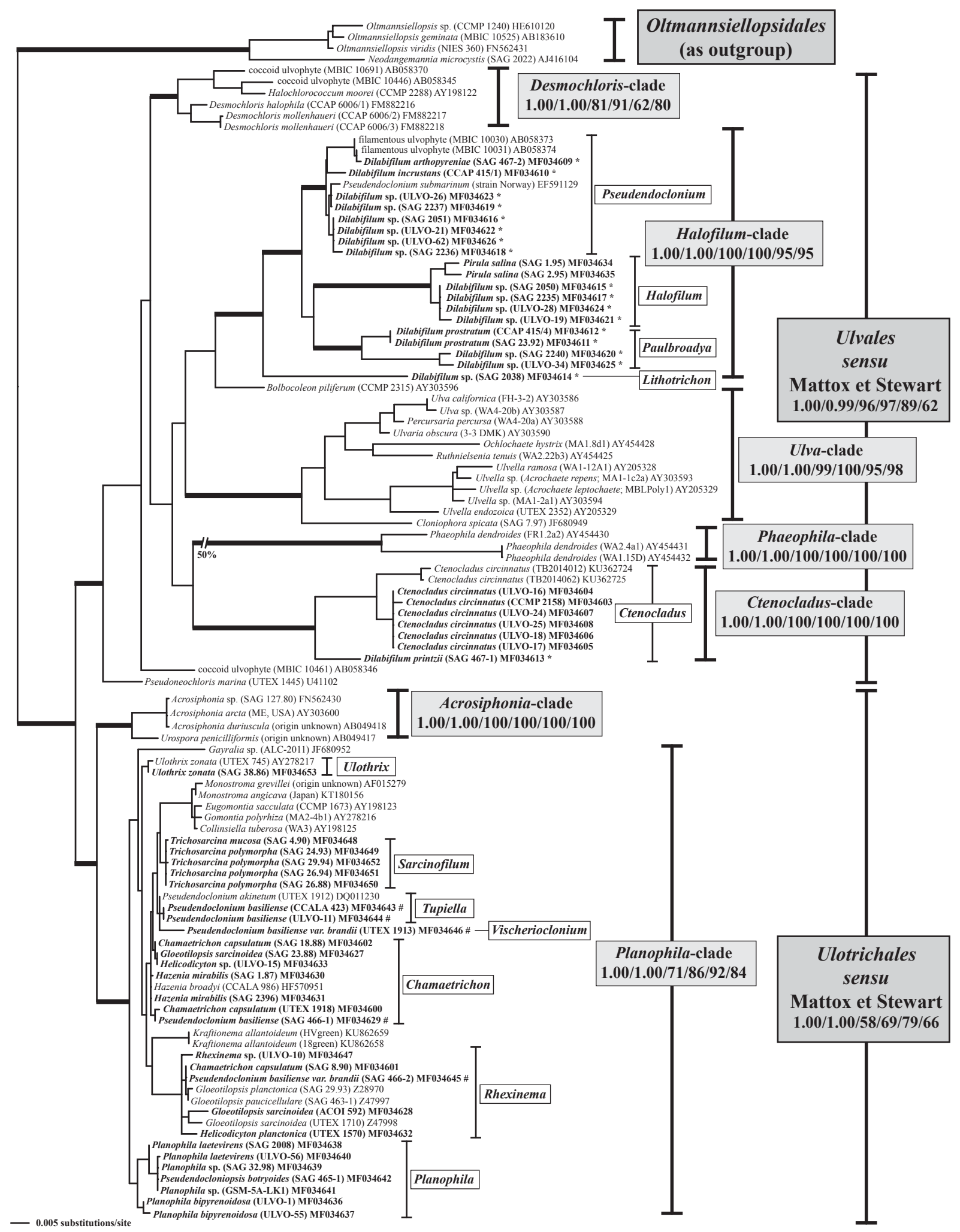

FIGURE 1. Molecular phylogeny of the Ulvophyceae based on SSU rDNA sequence comparisons. The phylogenetic tree shown was inferred using the maximum likelihood method based on a data set of 1770 aligned positions of 106 taxa using PAUP 4.0b10. For the analysis, the GTR $+\mathrm{I}+\mathrm{G}$ (base frequencies: A 0.23760, C 0.22733, G 0.28379, T 0.25128; rate matrix A-C 1.0063, A-G 2.3095, A-T 1.3005, C-G 0.7427, C-T 4.0954, G-T 1.0000) with the proportion of invariable sites $(\mathrm{I}=0.5552)$ and gamma shape parameter $(\mathrm{G}=$ 0.4527) was chosen, which was calculated as the best model by Modeltest 3.7. The branches in bold are highly supported in all analyses (Bayesian values $>0.95$ calculated with PHASE and MrBayes; bootstrap values $>70 \%$ calculated with PAUP using maximum likelihood, neighbor-joining, maximum parsimony and RAxML using maximum likelihood). The sister group of the Oltmannsiellopsis-clade was chosen as outgroup. The clade designations was given after the represented genera. The strains originally assigned as Dilabifilum and Pseudendoclonium basiliense are marked with * and \# behind the accession number, respectively. The generic names after taxonomic revision are given in white boxes. 
Considering this approach, we extracted the conserved region of ITS-2 from each of 54 strains as follows: (1) 16 base pairs of the 5.8S/LSU stem, (2) three basal base pairs of Helix I, (3) eleven base pairs of Helix II including the pyrimidine-pyrimidine mismatch, and (4) all base pairs of Helix III. The resulting data set was then aligned manually. These alignments have been translated into base pair alignment by usage of a number code for each base pair $(1=\mathrm{A}-\mathrm{U}$; $2=\mathrm{U}-\mathrm{A} ; 3=\mathrm{G}-\mathrm{C} ; 4=\mathrm{C}-\mathrm{G} ; 5=\mathrm{G} \cdot \mathrm{U} ; 6=\mathrm{U} \cdot \mathrm{G})$. The resulting number code of each strain is given in Figs S2. These barcodes of each genus were compared to detect compensatory base changes (CBCs), hemi-CBCs (HCBCs) and/or insertion/deletion, single or unpaired bases. The results are summarized in Table 1 and Figs S2.

TABLE 1. Genetic variability among SSU and ITS-2 rDNA sequences and species delimitation using the ITS2/CBC approach.

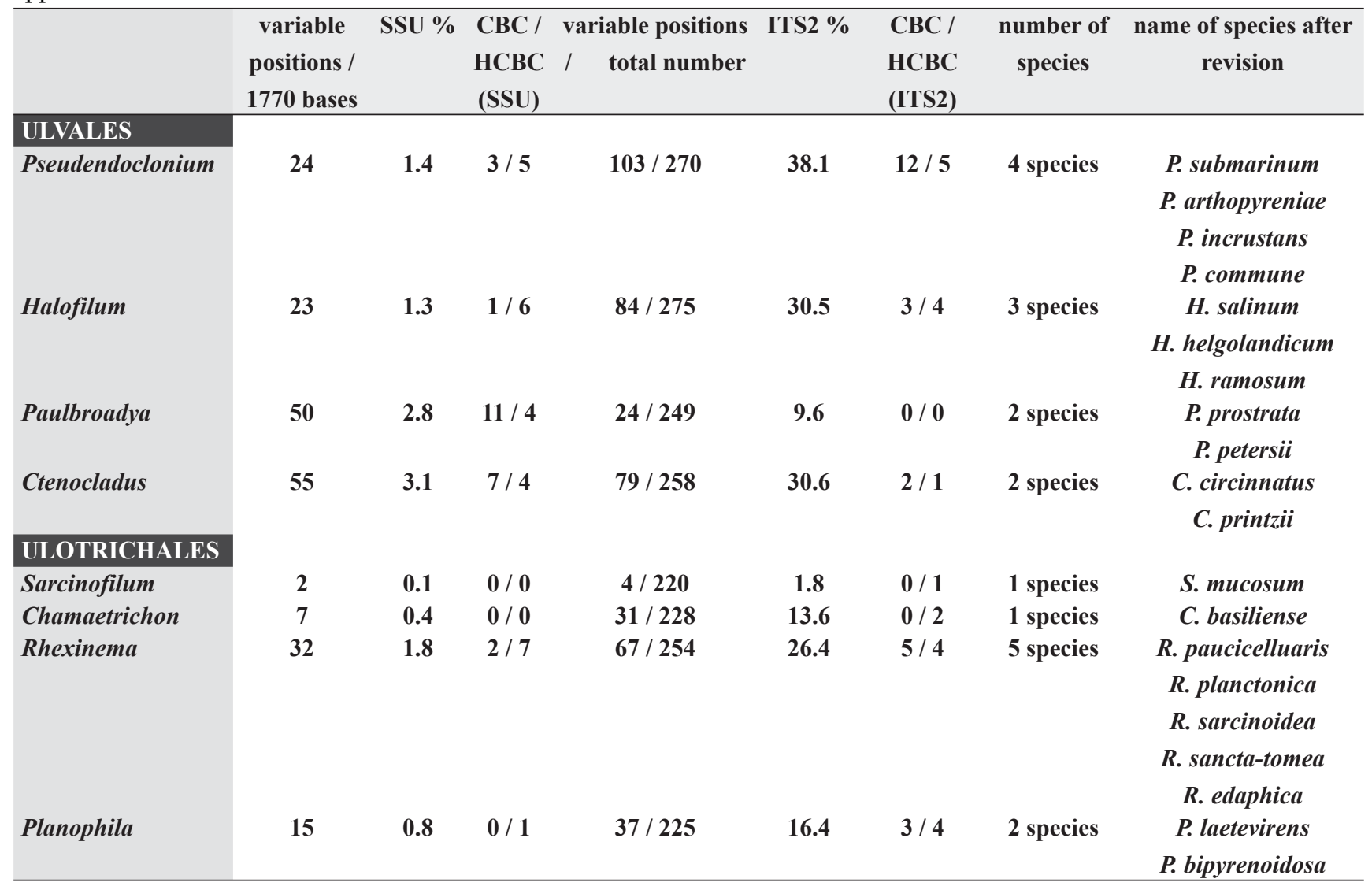

\section{Results}

\section{Phylogenetic distribution of non-marine Ulvophyceae}

Phylogenetic analyses of the SSU rDNA sequences clearly revealed that all non-marine ulvophytes were distributed into two major lineages within the Ulvophyceae s.str: Ulvales and Ulotrichales sensu Mattox et Stewart (Fig. 1). The Ulvales were subdivided into five clades named Desmochloris, Halofilum, Phaeophila, Ulva, and Ctenocladus. In addition, a few single lineages (Bolbocoleon piliferum and Pseudoneochloris marina) were also members of the Ulvales. The Ulotrichales was split into two clades (Acrosiphonia and Planophila). All clades and lineages were highly supported in all bootstrap and Bayesian analyses. The non-marine ulvophytes belonging to the Ulvales represented six lineages (= genera; see below), which were highly supported in all phylogenetic analyses. In contrast, those belonging to the Ulotrichales were distributed in the Planophila-clade, which could not be clearly assigned to genera using solely SSU rDNA sequences.

As shown in Fig. 1, most generic affiliations of the investigated strains were distributed in different clades and were often not closely related. For example, the strains named Dilabifilum ssp. (marked with an * in Fig.1) belonged to five lineages among the Ulvales. Even the assignment of the strains at the species level occurred in different phylogenetic groups, and these taxa were often closely related to strains that were originally identified as members of other genera. As an example within the Ulotrichales, the authentic strains of Pseudendoclonium basiliense and its variety brandii (marked with \# in Fig.1) were closely related to those of Chamaetrichon and Rhexinema, respectively. Another strains assigned as Pseudendoclonium basiliense (also marked with \#) even represented own lineages. 
To gain better phylogenetic resolution, we analyzed SSU and ITS rDNA sequences of the non-marine ulvophytes separately in two concatenated datasets (Ulvales and Ulotrichales; Figs 2-3). The SSU and ITS rDNA sequences were aligned according to their secondary structures.

The investigated strains belonging to the Ulvales (Fig. 2) were split into five lineages representing genera (Pseudendoclonium, Halofilum gen. nov., Paulbroadya gen. nov., Lithotrichon gen. nov., Ctenocladus; see details below). All clades were highly supported by different Bayesian (PHASE and MrBayes) and bootstrap (ML, RAxML, NJ, and MP) methods. Strains that had been previously assigned to the genus Dilabifilum were distributed in almost all lineages partly together with species of other genera, demonstrating the polyphyly of Dilabifilum. The authentic strains of D. arthopyreniae (SAG 467-2) and D. incrustans (CCAP 415/1) formed together with Pseudendoclonium submarinum, the type species of this genus, a monophyletic lineage (Pseudendoclonium). In contrast, the authentic strain of $D$. prostratum (SAG 23.92 = CCAP 415/4) was not closely related to that lineage and represented together with two unidentified Dilabifilum isolates, its own clade (Paulbroadya). D. printzii (SAG 467-1) was positioned together with strains designated Ctenocladus circinnatus in another lineage of the Ulvales (Ctenocladus). Other strains of Dilabifilum formed, together with strains assigned as Pirula salina, an alga that reproduced by budding in a monophyletic group (Halofilum gen. nov.; see below). Strain SAG 2038 showed no affiliation with one of the other clades and was a single member of the newly described genus Lithotrichon (see below "Taxonomic implications").

All other strains investigated in this study belonged to the order Ulotrichales (Fig. 3). In contrast to the results obtained for the SSU rDNA phylogeny (Fig. 1), which showed a weak resolution within this order, the phylogenetic analyses of the concatenated dataset resulted in another scenario. Seven lineages (Sarcinofilum gen. nov., Ulothrix, Rhexinema, Chamaetrichon, Tupiella gen. nov., Vischerioclonium gen. nov., and Planophila) could be clearly distinguished among this order, which represented the genera discussed in detail in the section "Taxonomic implications". All clades were highly supported in all of our analyses. Similar to the situation described above for Dilabifilum, the strains designated with the same generic and species names occurred in different lineages mixed together with members of other genera. For example, isolates of Pseudendoclonium basiliense and its variety brandii could be found either in the Chamaetrichon and Rhexinema clades or could form their own lineages (Tupiella and Vischerioclonium). Strains assigned to the Chamaetrichon capsulatum and Gloeotilopsis sarcinoidea occurred also in different lineages (Chamaetrichon and Rhexinema clades). Only the strains identified as members of the genera Trichosarcina (Sarcinofilum gen. nov.; see below) and Planophila are not mixed with other taxa and form monophyletic lineages.

\section{Species delimitation using ITS-2/CBC approach}

As shown in Figs 2 and 3, all lineages representing genera of the Ulvales and Ulotrichales were highly supported in all phylogenetic analyses. To support the molecular differentiation at generic and species levels, we analyzed the secondary structures of SSU and ITS-2 rRNA sequences. The secondary structures of all SSU sequences used for analyses presented in Figs 2-3 were compared with those shown in Fig. S1 of Ulothrix zonata (SAG 38.86). The two orders Ulvales and Ulotrichales as well as each genus were highly supported by synapomorphies in the secondary structures (data not shown). Within the highly supported genera the phylogenetic analyses (Figs 2-3) revealed several subclades, which represent species. For example, four separated lineages were observed in Pseudendoclonium, which are also highly supported in all analyses. Similar is the situation for the genera Halofilum, Paulbroadya, Ctenocladus, Rhexinema, and Planophila. All subclades among these genera are highly supported. Only within the genus Chamaetrichon the subdivision into lineages is not supported.

For species delimitation among these genera, we used the ITS-2/CBC approach, which were introduced by Demchenko et al. (2012), Darienko et al. $(2015,2016)$ for several groups of green algae. This approach relies on complete and accurate ITS-2 rDNA sequences without ambiguities, which then were folded using the constraints and methods described in Material \& Methods above. Using these constraints all programs resulted in almost identical secondary structures of all ITS-2 sequences (only minor differences in $\mathrm{G} \bullet \mathrm{U} / \mathrm{U} \bullet \mathrm{G}$ base pairs, which thermodynamically less stable fold in mfold than in the stochastic approach using CONTRAfold). The ITS-2 secondary structures of all investigated strains are very conserved and have three helices (Helix I-III sensu Mai and Coleman 1997), Helix IV is missing (see Figs S2). The conserved regions of the ITS-2 secondary structures were extracted and translated into a number code as described above in Material \& Methods. The number codes of strains belonging to one genus were compared to detect compensatory base changes for species discrimination. As summarized in Table 1, the subdivision within all genera into subclades as shown in Figs 2-3, which represent species, was supported by CBCs and HCBCs in the conserved region of ITS-2. For example, the presence of $12 \mathrm{CBCs}$ and 5 HCBCs supported the split of Pseudendoclonium into four species. For each species a unique barcode could be observed (see Figs S2). 


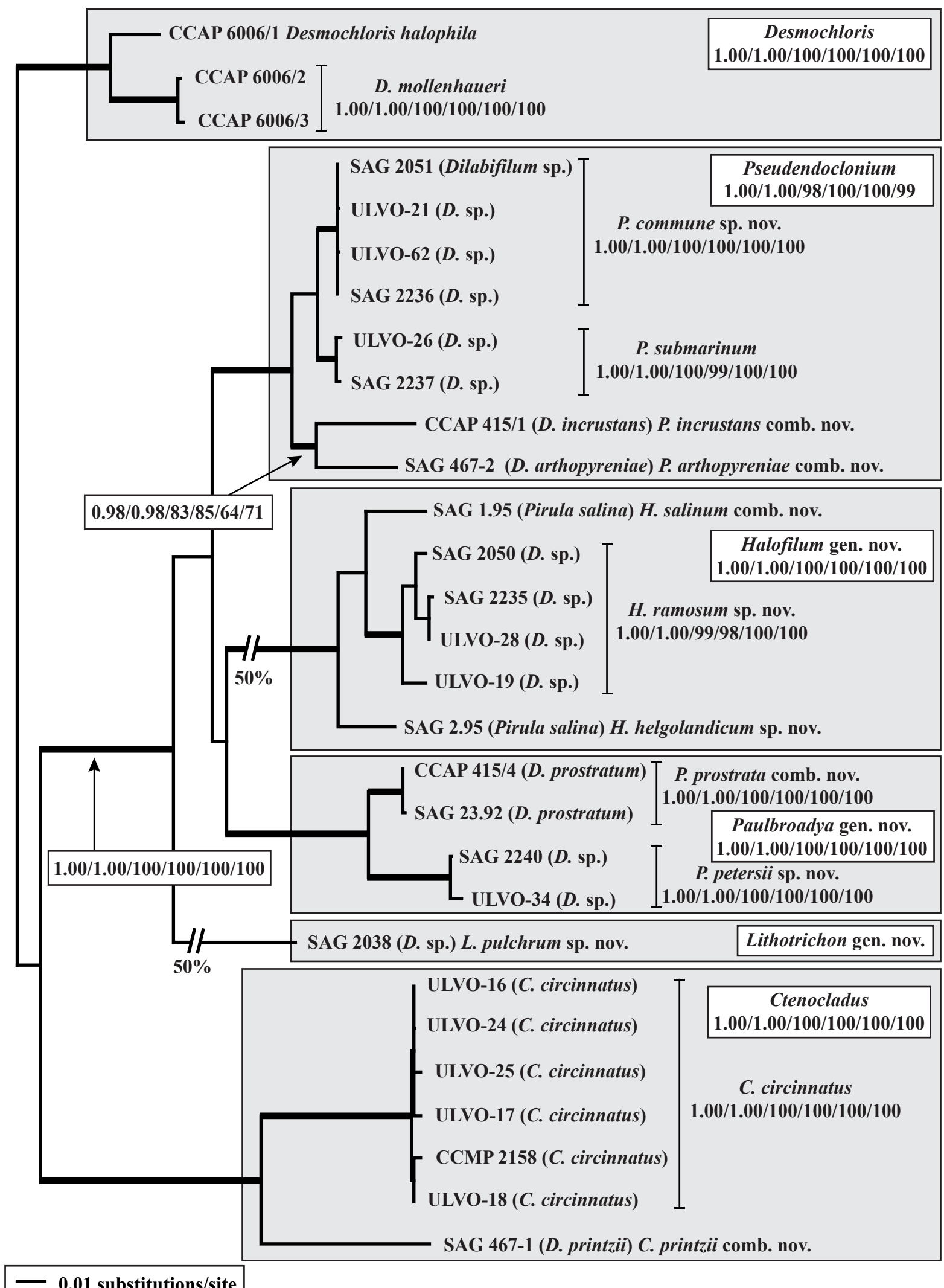

FIGURE 2. Molecular phylogeny of the Ulvales sensu Mattox and Stewart based on SSU and ITS rDNA sequence comparisons. The phylogenetic trees shown were inferred using the maximum likelihood method based on the data sets (2554 aligned positions of 29 taxa) using PAUP 4.0b10. For the analyses the best model was calculated by Modeltest 3.7. The setting of the best model was given as follows: GTR+I+G (base frequencies: A 0.2245, C 0.2728, G 0.2822, T 0.2204; rate matrix A-C 1.2613, A-G 1.7439, A-T 1.5854, C-G 1.1603, C-T 3.7924, G-T 1.0000) with the proportion of invariable sites $(\mathrm{I}=0.5454)$ and gamma shape parameter $(\mathrm{G}=0.6998)$. The branches in bold are highly supported in all analyses (Bayesian values $>0.95$ calculated with PHASE and MrBayes; bootstrap values $>70 \%$ calculated with PAUP using maximum likelihood, neighbor-joining, maximum parsimony and RAxML using maximum likelihood). The original designation of each strain is given in brackets after the strain number. 


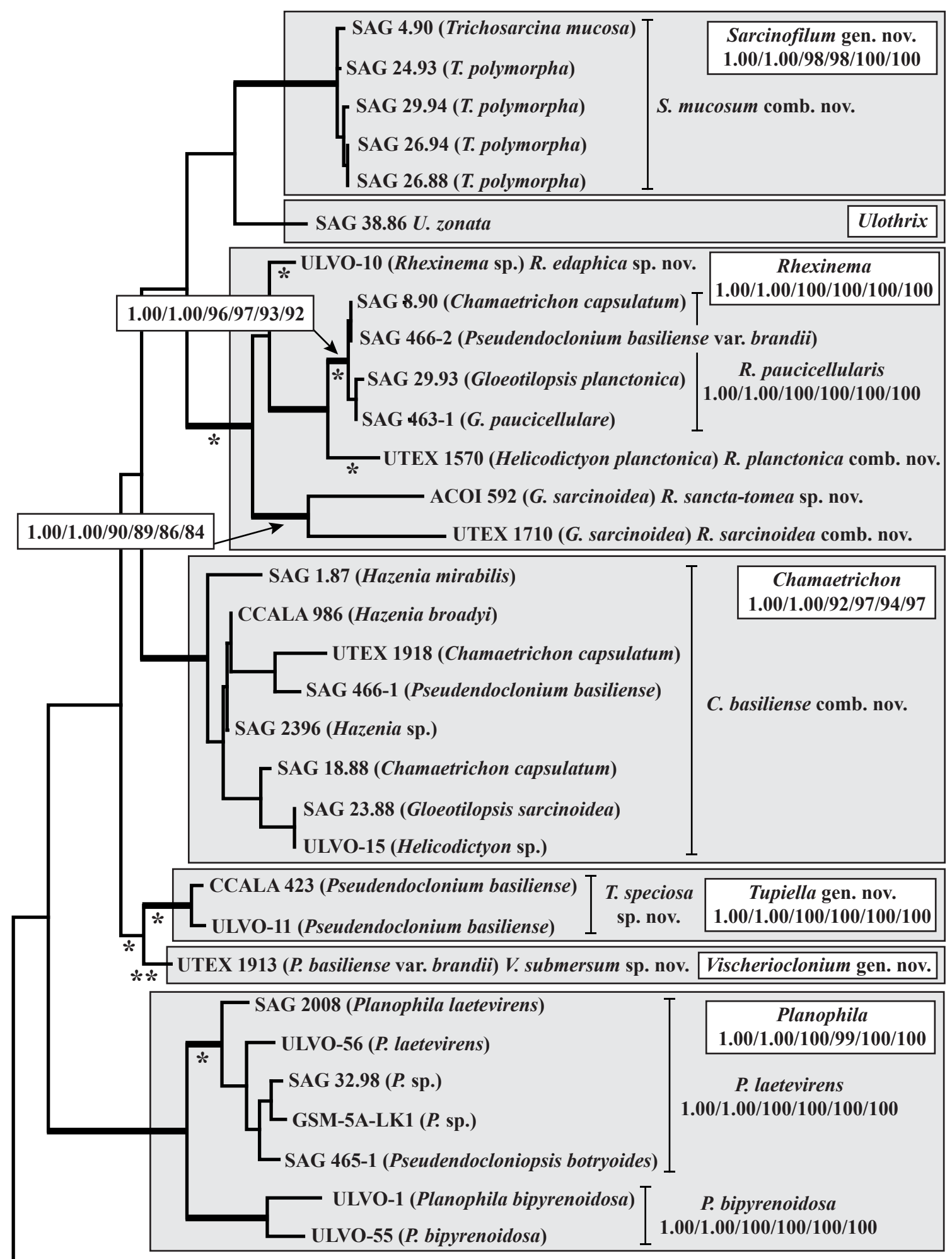

SAG 127.80 Acrosiphonia sp.

- 0.005 substitutions/site

FIGURE 3. Molecular phylogeny of the Ulotrichales sensu Mattox and Stewart based on SSU and ITS rDNA sequence comparisons. The phylogenetic trees shown were inferred using the maximum likelihood method based on the data sets (2355 aligned positions of 33 taxa) using PAUP 4.0b10. For the analyses the best model was calculated by Modeltest 3.7. The setting of the best model was given as follows: GTR $+\mathrm{I}+\mathrm{G}$ (base frequencies: A 0.2485, C 0.2314, G 0.2668, T 0.2534; rate matrix A-C 1.5764, A-G 3.1118, A-T 1.7950, C-G 0.7531, C-T 7.2031, G-T 1.0000) with the proportion of invariable sites $(\mathrm{I}=0.7371)$ and gamma shape parameter $(\mathrm{G}=0.4509)$. The branches in bold are highly supported in all analyses (Bayesian values $>0.95$ calculated with PHASE and MrBayes; bootstrap values $>70 \%$ calculated with PAUP using maximum likelihood, neighbor-joining, maximum parsimony and RAxML using maximum likelihood). The original designation of each strain is given in brackets after the strain number. The branches marked with * and ** were reduced in length to $25 \%$ and $10 \%$, respectively. 
All species of the other genera mentioned in Table 1 were also supported by CBCs and HCBCs in the ITS- 2 sequences with one exception. The two species of Paulbroadya had similar ITS-2 sequences with little variations (9.6\%), and no $\mathrm{CBC} / \mathrm{HCBC}$ could be discovered; however, in contrast to ITS-2 they showed eleven CBCs and four HCBCs in the SSU sequences. The strains belonging to Chamaetrichon, which showed no resolution within the genus using SSU and ITS (see Fig. 3), could also not be subdivided into groups using the ITS-2/CBC approach. Only two HCBCs were discovered among the strains. Therefore, the separation into different species within Chamaetrichon was not supported.

\section{Morphology and identification of the investigated strains}

As described above, the investigated strains were assigned to genera and species, which do not correspond to their phylogeny presented in Figs 1-3. This raises the question of whether these strains were misidentified or the features for identification were too variable or missing. To answer this question, we studied the morphology of all strains under different growth conditions, as described in Material \& Methods. The morphology of all authentic strains was consistent with the original species descriptions, and all assignments at species level in Fig. 1 are correct with one exception. The strain SAG 29.93 designated as Gloeotilopsis planctonica did not fit with the original species description provided by Iyengar \& Philipose (1956). This strain could be identified as Pleurastrum paucicellulare using the key of Ettl \& Gärtner (1995).

All strains of the Ulotrichales had a similar morphology: cell packages with different tendencies to form branched pseudofilaments, uniserial or sometimes biserial filaments, often embedded in common mucilage. Details about the morphological features are described in the section "Taxonomic implications". Some features such zoospore formation could not be observed in all strains. All investigated strains showed a high phenotypic plasticity as demonstrated in Figs 4-23, which highlighted the difficulties related to identification at generic and species levels.

The investigated members of the Ulvales are mostly short or long branched filaments, with each cell having a plate-like chloroplast and a pyrenoid, often forming within the middle of the thallus a pseudoparenchymal plate. The differences between genera are not clear: special branching and long cells by Dilabifilum or short branched, easily breaking down filaments by Pseudendoclonium. All investigated authentic strains of Ulvales correspond to the type descriptions, except for Pseudendoclonium printzii, which no longer forms filaments. All attempts to stimulate filament formation, such as growth in different media, a short transfer cycle, and different temperatures were unsuccessful.

Another exception are strains previously assigned to the Pirula. Both investigated strains characterized by special reproduction of budding, containing parietal chloroplasts with a single pyrenoid and correspond to the type description of Heterogonium salinum (Dangeard 1911, 1912).

\section{Discussion}

\section{Molecular phylogeny of non-marine Ulvophyceae}

Our investigations of terrestrial and freshwater green algae have revealed that all of them belong to the Ulvophyceae. The species identification and their affiliation to the Ulvophyceae is often very difficult and can be only performed by studying of strains in culture under different conditions to discover all life stages. The typical characteristics of the Ulvophyceae are mostly ultrastructural features, such as the counterclockwise orientation of the basal bodies in the flagellated cells and the type of cytokinesis (Mattox \& Stewart 1984, Sluiman 1989; see also review of Pröschold \& Leliaert 2007). The only clear characteristic of Ulvophyceae, which can be observed by light microscopy, is the occurrence of a "Codiolum"-stage (zygote) during sexual reproduction (Kornmann 1973). For Ulothrix zonata, a "Codiolum"-stage has been observed by Dodel (1876). However, for most freshwater and terrestrial ulvophytes, the sexual reproduction is unknown. Therefore, the molecular phylogeny of DNA sequences (SSU, ITS rDNA or rbcL) is used for most of the recent investigations studying Ulvophyceae. New lineages could be discovered by those analyses. For example, Watanabe \& Nakayama (2007) have revealed that two freshwater and terrestrial green algae originally considered to be chlorophytes, belong to the ulvophytes (Ignatius tetrasporus, Pseudocharacium americanum). Skaloud et al. (2013b) have demonstrated that coccoid green algae of the genus Scotinosphaera (previously known as Kentrosphaera) are members of the Ulvophyceae s.lato. Our phylogenetic analyses of the Ulvophyceae s.str. presented in Fig. 1 showed that two major lineages of the Ulvophyceae contain non-marine strains: Ulvales and Ulotrichales sensu Mattox and Stewart. In contrast to the domination of these orders by marine species, our study clearly revealed that the biodiversity of non-marine taxa among these groups are much higher than expected. These strains investigated in our study were distributed in five and seven genera of the Ulvales and Ulotrichales, respectively. Five out of them 
are newly discovered. The high biodiversity was also confirmed by Wetherbee \& Verbruggen (2016), who recently described a new genus (Kraftionema) among the Ulvophyceae. As shown in Fig. 1, this genus is a member of the Ulotrichales, which is closely related to Rhexinema. Liu et al. (2016) collected samples of Ctenocladus from two lakes in Tibet, China. These are closely related to our Ctenocladus circinnatus in SSU phylogeny. However, they differ in SSU sequences to our investigated strains. Unfortunately, no ITS sequences of the Chinese samples were available, and no strains have been deposited in public culture collections. Therefore, these strains cannot be affiliated at the species level, but it seems that they belong to a third species of Ctenocladus.

\section{Species concept among non-marine ulvophytes using the ITS-2/CBC approach}

Many species and genera are traditionally described using the morphological species concept. However as highlighted above, this concept is artificial because of the high phenotypic plasticity. As a consequence we applied the ITS-2/CBC approach for species delimitation. This approach has been used for several green algal genera (see Darienko et al. 2016 and references therein) and takes the occurrence of compensatory base changes in the conserved region of ITS- 2 into account for species differentiation. Coleman (2009) has demonstrated that if two specimens of a monophyletic lineage have at least one $\mathrm{CBC}$ in this region of ITS-2 they cannot mate and belong to different biological species. We applied this approach to the twelve highly supported genera of the Ulvales and Ulotrichales (see Figs 2-3) and recognized 24 species, almost all of which differ from each other in at least in one CBC. Only the two species of Paulbroadya have no CBC in ITS-2, but eleven in SSU (Table 1). The translation into number-coded alignment of the conserved ITS-2 region allows an easy recognition of $\mathrm{CBCs}$ and $\mathrm{HCBCs}$, as demonstrated in Figs $\mathrm{S} 2$ for each genus.

As shown in Table 1, the genetic variability of the genera differs in both orders of the Ulvophyceae. Whereas the genera Pseudendoclonium, Halofilum, and Ctenocladus (Ulvales) have more than $30 \%$ variable positions within ITS-2, those of the Ulotrichales vary a maximum of $26 \%$ (Rhexinema). Most of the others have only $10-16 \%$ variable positions. Despite different evolutionary rates among the genera, the ITS-2/CBC approach could distinguish species within each genus in our study. Therefore, this approach is probably applicable for species delimitation of all Ulvophyceae.

\section{Historical overview and taxonomic implications}

As shown in the figures and tables above, investigations of isolated strains require many taxonomic changes and description of new genera and species, which will be discussed in detail in the following chapters. Most taxonomic problems occurred because of a similar morphology with a high phenotypic plasticity among the investigated strains. In particular, the morphological changes caused different taxonomic classifications depending on various salinities. Even the classification at higher levels (families and orders) remain unresolved and require further studies. In the meantime, we are using the system introduced by Mattox and Stewart (1984) and modified by O'Kelly and Floyd (1984) and Sluiman (1989). At present we have not revised the system at the order and family levels but only at the generic and species levels of non-marine ulvophytes:

\section{The order Ulvales sensu Mattox and Stewart}

\section{Pseudendoclonium, Pseudopleurococcus, or Dilabifilum, how we should name them?}

The genus Pseudendoclonium with its type species P. submarinum was described by Wille (1901). The type locality of this species was a floating wooden piece on coastal water in Drøbak (Norway). Since the first description, approximately 20 more species of Pseudendoclonium have been described from freshwater and marine habitats (John \& Johnson 1989). Some of them were originally assigned to other genera. For example, Pseudendoclonium printzii (Vischer) Bourrelly was described as a member of the genus Pseudopleurococcus by Vischer (1933). Two species of Pseudopleurococcus (P. vulgaris and P. botryoides) were originally described by Snow (1899) from the bark of trees. Unfortunately, since the first description, no reports of both these species have been published. Therefore, the taxonomic status of this genus remains unresolved. Both genera, Pseudendoclonium and Pseudopleurococcus, have a similar morphology and differ only in the lack of zoospore formation in Pseudopleurococcus. Vischer \& Klement in Vischer (1953) described another species of Pseudopleurococcus, P. arthopyreniae, which is a photobiont of the lichen Arthopyrenia kelpii. TschermakWoess (1970) discovered on the cultured type material of this species zoospores and transferred this species together with the other species $P$. printzii and $P$. incrustans, which were also described by Vischer (1956), to the newly erected genus Dilabifilum. Broady \& Ingerfeld (1993) isolated D. prostratum in epilithic crusts on Ross Island (Antarctica). Johnson \& John (1990) questioned the establishment of Dilabifilum based on comparative studies of cultured material. They found that the diagnostic features were very variable, which demonstrated the high phenotypic plasticity among the species of Dilabifilum. Thüs et al. (2011) discovered that many photobionts of the lichen family Verrucariaceae belong to the genus Dilabifilum, some of which were investigated herein. 
In our study, we analyzed almost all available strains including the authentic strains of the above described species, which were designated members of the three genera. The phylogenetic analyses of SSU and ITS rDNA sequences as well as the ITS-2/CBC approach (Figs 1-2, Table 1) clearly demonstrated that the three genera are polyphyletic. Unfortunately no type strain of Pseudendoclonium submarinum is available; however, Mullins (2007) sequenced the SSU rDNA of a strain that was isolated by Ruth Nielsen from the type locality and compared the morphology with the original description. He concluded that this material fits the original diagnosis of Wille. As shown in Fig. 1 Pseudendoclonium submarinum is closely related to Dilabifilum arthopyreniae and D. incrustans as well as several unidentified Dilabifilum strains. Only D. printzii belongs to another genus (Ctenocladus; see below). The strain SAG 2038 designated Dilabifilum sp. is also not closely related to this group and represents a new genus (see below). As a result of these findings the following nomenclatural changes are necessary.

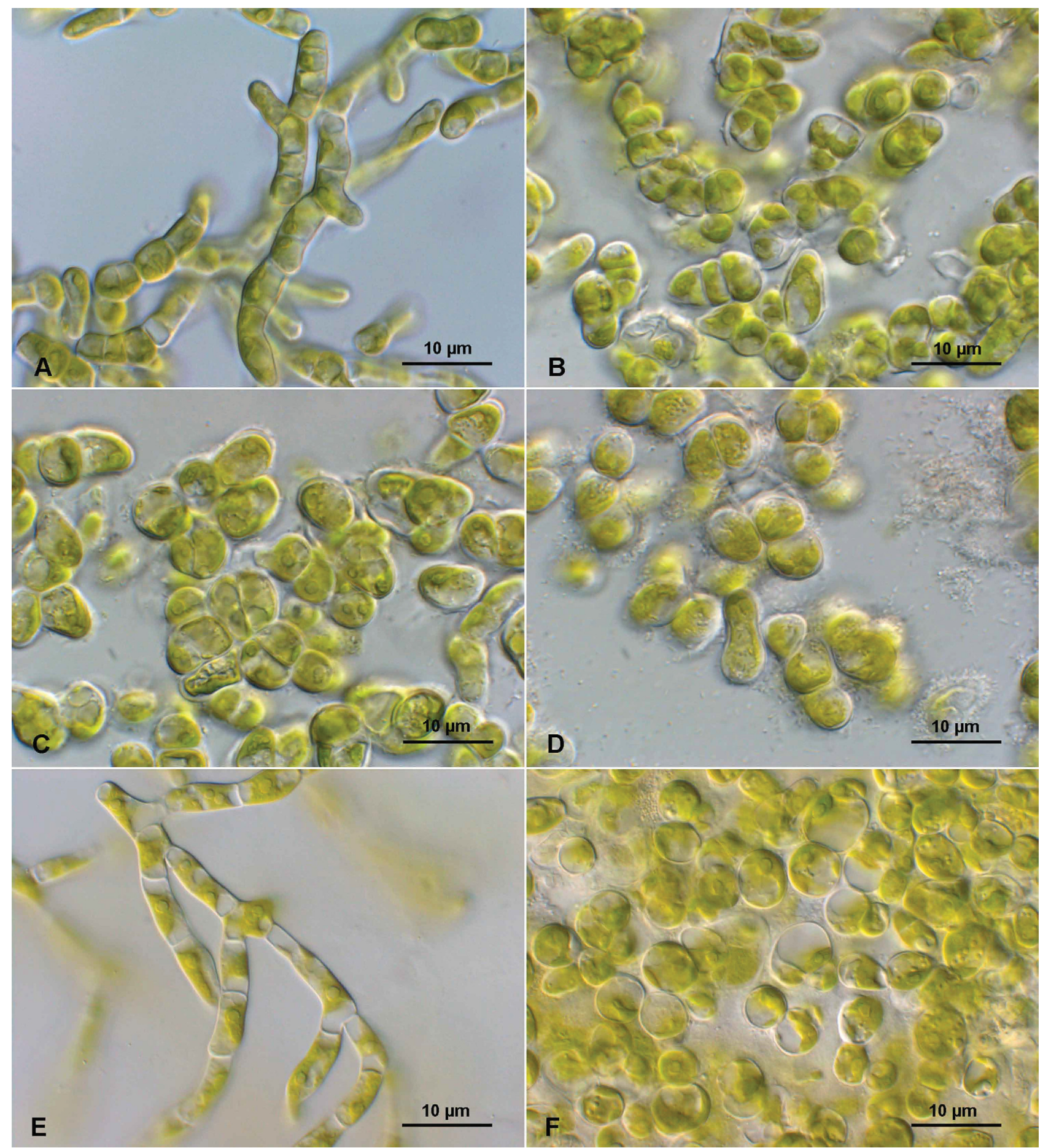

FIGURE 4. Overview about the morphology of the investigated Pseudendoclonium strains grown on 3NBBM medium. A. ULVO-21, B. ULVO-29, C. ULVO-26, D. SAG 2237, E. SAG 467-2, F. CCAP 415/1. 
Pseudendoclonium Wille 1901, Christiania Vid.-Selsk. Skr. M.-N. Kl. 6: 29.

Synonym: Dilabifilum Tschermak-Woess 1970, Österr. Bot. Z. 118: 452, 453 (diagnosis latina)

Investigated strains: CCAP 415/1, SAG 2051, SAG 2236, SAG 2237, SAG 467-2, ULVO-21, ULVO-26, ULVO62 (Figs 4-6).

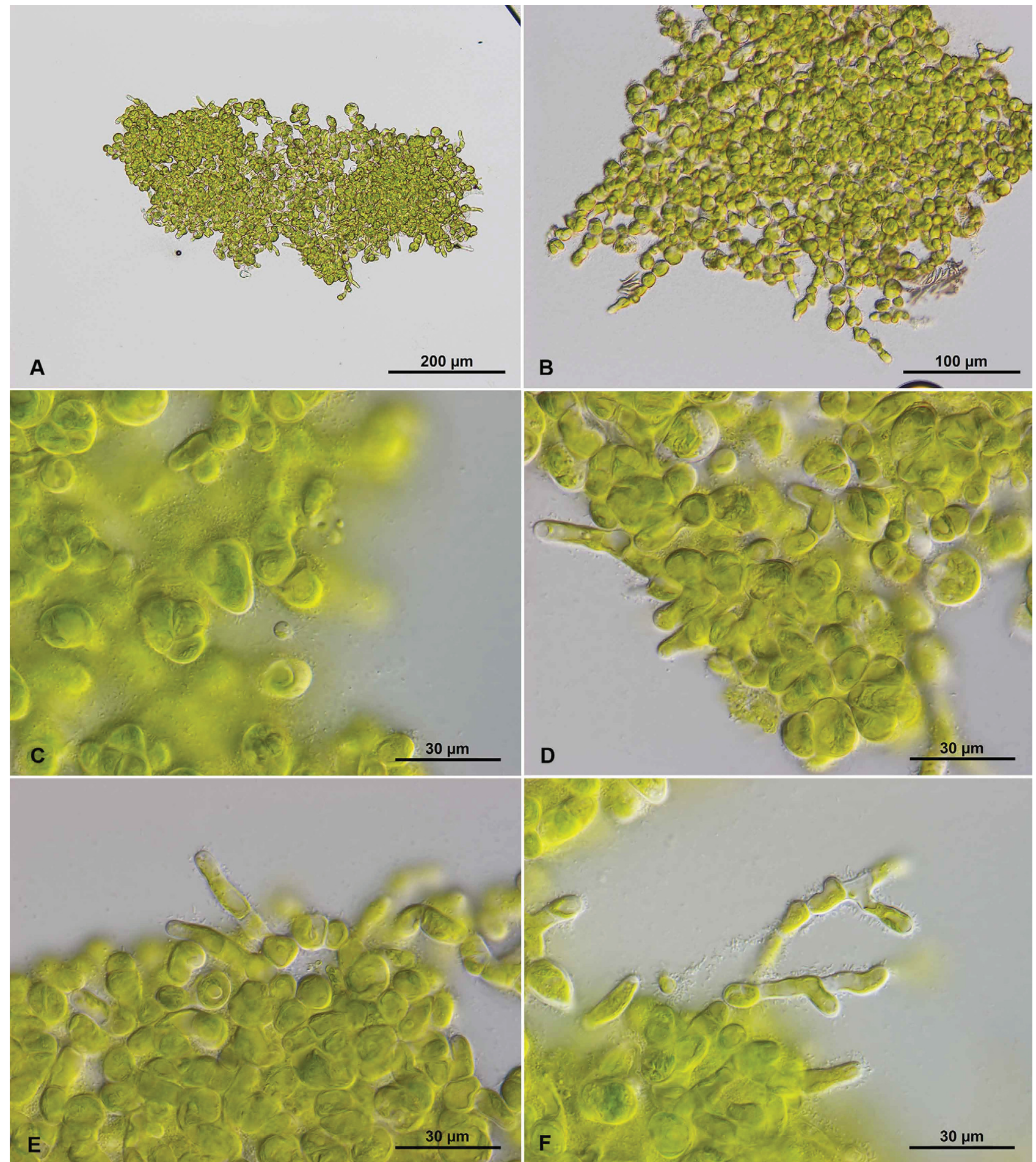

FIGURE 5. Morphology of Pseudendoclonium submarinum SAG 2237 grown on SWES medium.

Pseudendoclonium submarinum Wille 1901, Christiania Vid.-Selsk. Skr. M.-N. K1. 6: 29, figs. 101-134 (Fig. 5AF).

Lectotype (designated herein): Fig. 107 in Wille (1901).

Epitype (designated herein): The authentic strain SAG 2237 is permanently cryopreserved in metabolically inactive state (cryopreserved in liquid nitrogen) in the SAG, University of Göttingen, Germany.

ITS-2 DNA Barcode: PSE1 in Figs S2. 


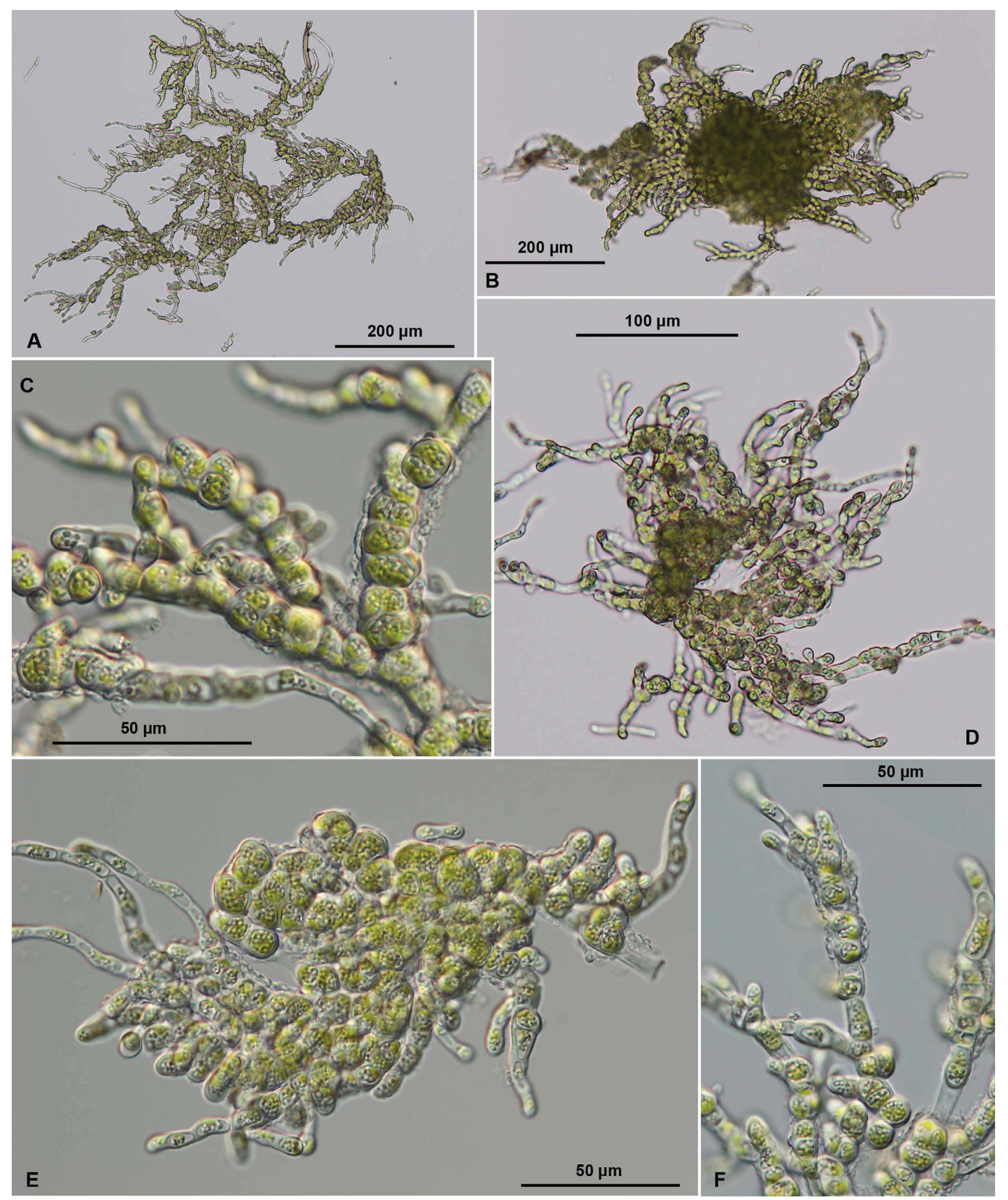

FIGURE 6. Morphology of Pseudendoclonium commune SAG 2051 grown on 1/2SWES medium.

Pseudendoclonium arthopyreniae (Vischer et Klement) Darienko et Pröschold comb. nov. (Fig. 4E)

Basionym: Pseudopleurococcus arthopyreniae Vischer et Klement in Vischer 1953, Ber. Schweiz. Bot. Ges. 63: 177-178 (diagnosis latina), figs. 6, 1-8.

Synonym: Dilabifilum arthopyreniae (Vischer et Klement) Tschermak-Woess 1970, Österr. Bot. Z. 118: 452, 453.

Lectotype (designated herein): Fig. 6, 2 in Vischer (1953). 
Epitype (designated herein): The authentic strain SAG 467-2 is permanently cryopreserved in metabolically inactive state (cryopreserved in liquid nitrogen) in the SAG, University of Göttingen, Germany.

ITS-2 DNA Barcode: PSE2 in Figs S2.

Pseudendoclonium incrustans (Vischer) Darienko et Pröschold comb. nov. (Fig. 4F)

Basionym: Pseudopleurococcus incrustans Vischer in Binz et Vischer 1956, Verh. Naturf. Ges. Basel 67: 208 (diagnosis latina), fig. 3 1-11.

Synonym: Dilabifilum incrustans (Vischer) Tschermak-Woess 1970, Österr. Bot. Z. 118: 452.

Lectotype (designated herein): Fig. $34 b$ in Binz and Vischer (1956).

Epitype (designated herein): The authentic strain CCAP 415/1 is permanently cryopreserved in metabolically inactive state (cryopreserved in liquid nitrogen) in CCAP, SAMS, Scotland.

ITS-2 DNA Barcode: PSE3 in Figs S2.

\section{Pseudendoclonium commune Darienko et Pröschold sp. nov. (Fig. 6A-F)}

Diagnosis: Plants on liquid SWES medium up to $1 \mathrm{~mm}$ consist of prostrate and erected filaments. The system of prostrate filaments is very dense and formed from packages or pluriseriate filaments. The vegetative cells of prostrate system are rounded, $6.4-10.4 \mu \mathrm{m}$ in diameter, with a thick cell wall. The erect system is formed from short filaments, consisting of a maximum of 20 cells. The cells are cylindrical $(10.8 \times 5.4 \mu \mathrm{m}$ till $16.5 \times 5.4 \mu \mathrm{m})$ and generally $2-3$ times longer than broad. The end cells are $8.0 \times 3.2 \mu \mathrm{m}$ till $12.0 \times 3.2 \mu \mathrm{m}$. Branching is mostly unilateral, but sometimes it is also bilateral. Cells are uninucleate. The chloroplast is parietal, usually filling the cell, with a pyrenoid. Zoospores are not observed.

The species differs from other members of the genus by SSU-ITS sequences.

Habitat: Photobiont, on coastal rocks (Pelvetia-zone).

Type locality: Wales, Anglesey (Ynys Mon), Aberfraw.

Holotype (designated herein): The authentic strain SAG 2051 is permanently cryopreserved in metabolically inactive state (cryopreserved in liquid nitrogen) in the SAG, University of Göttingen, Germany.

Iconotype (designated herein in support of the holotype): Fig. 6 in this study.

ITS-2 DNA Barcode: PSE4 in Figs S2.

Comment: This species is probably widely distributed as photobiont and free-living. Additional strains: SAG 2236 - photobiont of Verrucaria maura, Öland, Sweden; ULVO-21 - free-living biofilm on coastal rock ( $3 \mathrm{~m}$ high), Snake Island, Black Sea, Ukraine; ULVO-62 - free-living biofilm on concrete block in the tidal zone on Oakland beach, RI, USA.

Paulbroadya Darienko et Pröschold gen. nov.

Diagnosis: Algae forms prostrate and erect systems of filaments. Prostrate system is formed from rounded cells often gathered into cell packages. The erect system is richly branched uni- or bilateral. Cells are uninucleate, posses a parietal chloroplast and one pyrenoid. The pyrenoid is surrounded by starch grains. Reproduction by zoospores is not known.

Differs from other genera by SSU-ITS sequences.

Type species (designated herein): Paulbroadya prostrata (Broady et Ingerfeld) Darienko et Pröschold comb. nov.

Investigated strains: CCAP 415/4, SAG 23.92, SAG 2240, ULVO-34 (Figs 7-8).

Paulbroadya prostrata (Broady et Ingerfeld) Darienko et Pröschold comb. nov. (Fig. 7A-G)

Basionym: Dilabifilum prostratum Broady et Ingerfeld 1993, Eur. J. Phycol. 28: 26 (diagnosis latina), fig. 1 a-e (iconotypus).

Epitype (designated herein in support of the iconotype): The authentic strain SAG 23.92 is permanently cryopreserved in a metabolically inactive state (cryopreserved in liquid nitrogen) in the SAG, University of Göttingen, Germany.

Comment: This species is probably not endemic in Antarctica.

ITS-2 DNA Barcode: PAU1 in Figs S2. 


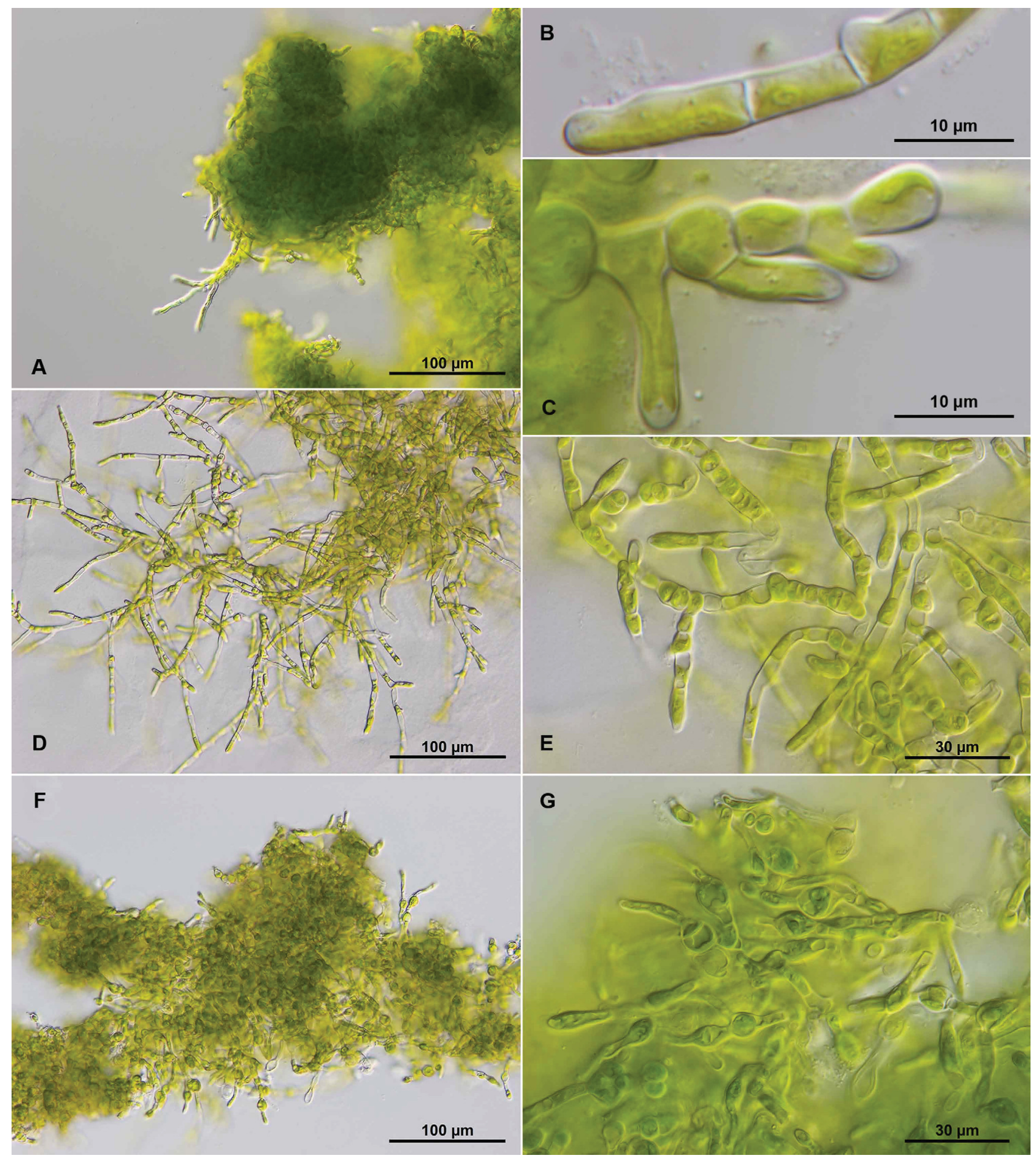

FIGURE 7. Morphology of Paulbroadya prostrata SAG 23.92 grown on 1/2SWES medium.

Paulbroadya petersii Darienko et Pröschold sp. nov. (Fig. 8A-G)

Diagnosis: The thalli of mature plants are cushion-shaped, composed from prostrate and branched filaments, with a maximum length of 2-3 mm. The prostrate system is formed of square cells that are often gathered into cell packages with cell size of 5.2-5.5-6.8 $\mu \mathrm{m}$. The erect system is richly branched uni- or bilateral. Intercalary cells of erected filaments 5.5-10.5 $\mu \mathrm{m}$ long $\times 5.2-6.8 \mu \mathrm{m}$, up to twice as long as broad. Terminal cells are slightly pointed, 14.5-21.2 $\mu \mathrm{m}$ long $\times 4.8-5.2 \mu \mathrm{m}$ wide, and are twice to four times as long as broad. Cells are uninucleate, with parietal plate-like chloroplast and one pyrenoid. The pyrenoid is surrounded by starch grains. Asexual reproduction occurs by formation of zoospores. Zoosporangia are pear-shaped and usually produced in the prostrate system of filaments. Zoosporangia $11.2-21.2 \mu \mathrm{m}$ long $\times 5.5-8.1 \mu \mathrm{m}$ wide. Zoospores are released by rupture of sporangia on the broad side of sporangia. Zoospores are quadriflagellated, very small $(4.5-5.0 \times 3.7-4.0 \mu \mathrm{m})$, with an anterior stigma. 


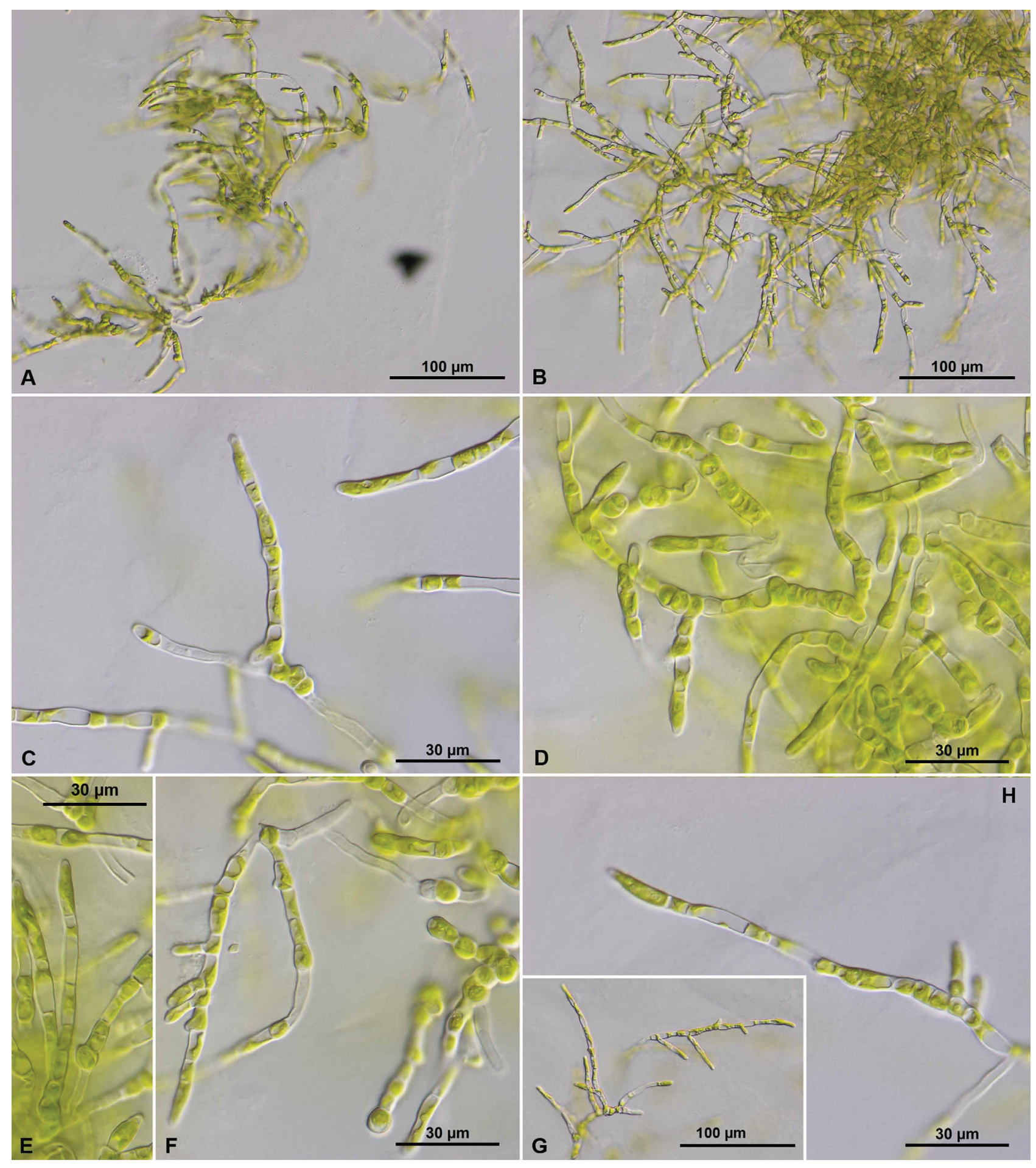

FIGURE 8. Morphology of Paulbroadya petersii SAG 2240 grown on SWES medium. A, B. general view of plants, C-G. morphology of filaments in two-weeks of growth.

The species differs from similar species by SSU-ITS sequences.

Habitat: Symbiont of Verrucaria mucosa.

Type locality: Roscoff, Brittany, France.

Holotype (designated herein): The authentic strain SAG 2240 is permanently cryopreserved in a metabolically inactive state (cryopreserved in liquid nitrogen) in the SAG, University of Göttingen, Germany.

Iconotype (designated herein to support of the holotype): Fig. 8 in this study.

Etymology: The species named in the honor of Dr. Akira Peters, who provide us the strains of Verrucaria photobionts. 
Comment: This species is distributed at least in the cold water of the North Atlantic as photobiont of Verrucaria mисоsa: SAG 2240 - Roscoff, Brittany, France and ULVO-34 - Oban, Scotland.

ITS-2 DNA Barcode: PAU1 in Figs S2 (barcode is identical with P. prostrata, but differ in SSU rDNA sequences).

Lithotrichon Darienko et Pröschold gen. nov.

Diagnosis: The thalli of mature plants are cushion-shaped, composed of prostrate and branched filaments. The prostrate system consists of rounded sarcinoid-like packages. The branched filaments are short and appear on the margin of the prostrate system. Vegetative cells contain parietal plate-like chloroplasts with a pyrenoid. Reproduction occurs by vegetative division and by zoospores.

The genus differs from similar genera by SSU-ITS sequences.

The type species (designated herein): Lithotrichon pulchrum Darienko et Pröschold sp. nov.

Investigated strain: SAG 2038 (Fig. 9).

\section{Lithotrichon pulchrum Darienko et Pröschold sp. nov. (Fig. 9A-I)}

Diagnosis: Plants in liquid 1/2 SWES medium up to $0.5 \mathrm{~mm}$ consist of prostrate and erected filaments. The system of prostrate filaments is very prominent and is formed from three-dimensional packages. The vegetative cells of the prostrate system are rounded or compressed from the sides, 5.9-8.8 $\mu \mathrm{m}$ in diameter, with a thick cell wall. Vegetative cells usually contain one or two large vacuoles. The erect system formed from short filaments consists of several cells (max. 10 cells). The end cells of plants are cylindrical, sometimes curved, 12.0-23.5 $\mu \mathrm{m}$ long $\times 3.5-5.5$ $\mu \mathrm{m}$ wide and generally $2-4$ times longer than broad. Branching is mostly bilateral. Cells are usually uninucleate, but sometimes the longest cells contain two nuclei and two pyrenoids (state before dividing?). Chloroplasts are parietal, usually filling the cell, with a pyrenoid. Zoosporangia are oval and approximately $16.2 \mu \mathrm{m}$ in diameter, containing 8 zoospores. Zoospores are ovoid, 7.0-7.5 $\mu \mathrm{m}$ long $\times 4.0-4.5 \mu \mathrm{m}$ wide with an anterior stigma. Zoospores are released by sudden fracture of the cell wall.

Habitat: Photobiont from lichen Verrucaria rheitrophila.

Type locality: Gladenbacher Bergland, near Dillenburg and Wetzlar, submerged approx. $10 \mathrm{~cm}$ below the water surface.

Holotype (designated herein): The authentic strain SAG 2038 is permanently cryopreserved in a metabolically inactive state (cryopreserved in liquid nitrogen) in the SAG, University of Göttingen, Germany.

Iconotype (designated herein in support of the holotype): Fig. 9 in this study.

ITS-2 DNA Barcode: LIT1 in Figs S2.

\section{Pirula versus Heterogonium}

The genus Pirula with its type species $P$. gemmata was originally described by Snow $(1911,1912)$. She observed this species from samples collected in Switzerland and Guatemala. Printz (1927) transferred another species to Pirula, which was described by Dangeard $(1911,1912)$ as Heterogonium salinum from a marine habitat. Pascher $(1939,1944)$ synonymized the type species of Pirula with Heterococcus, a xanthophycean genus, based on the lack of a pyrenoid and the presence of several chloroplasts per cell. The taxonomic change of Heterogonium salinum to Pirula is not supported. This transfer was also questioned by Gayral and Lepailleur (1969) because of differences in morphology and ecology (freshwater versus marine). However, the generic name Heterogonium is already preoccupied for a tropical fern species by Presl (1851). Therefore, for the species found by Dangeard, the new generic name Halofilum is proposed (see below). In addition, several strains originally assigned as Dilabifilum sp. are closely related to this species and represent new species, which will be erected below.

Halofilum Darienko et Pröschold gen. nov.

Synonym: Heterogonium Dangeard 1911 non Heterogonium Presl 1851

Diagnosis: The thallus consists of dense, relatively short branched or easily disintegrating filaments. Vegetative cells have a parietal chloroplast with a pyrenoid, single nucleus and several big vacuoles. Reproduction occurs by budding or by vegetative division. Reproduction by zoospores is unknown.

Differs from other genera by SSU-ITS sequences.

The type species (designated herein): Halofilum salinum (Dangeard) Darienko et Pröschold comb. nov.

Investigated strains: SAG 1.95, SAG 2.95, SAG 2050, SAG 2235, ULVO-19, ULVO-28 (Figs 10-11). 


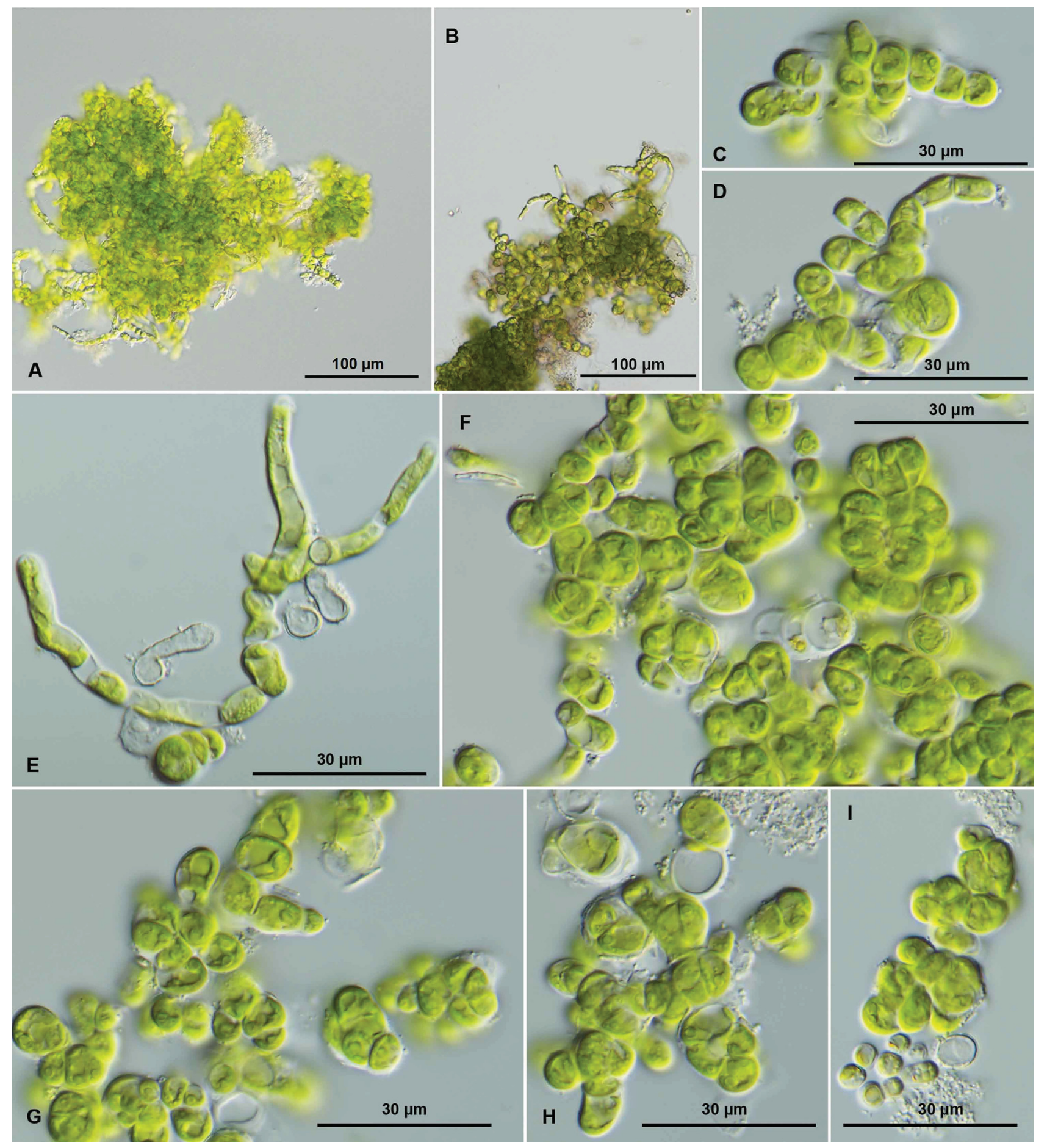

FIGURE 9. Morphology of Lithotrichon pulchrum SAG 2038 grown on 1/2SWES medium. A, B. general view of plants, C-E. young plants, F-H. packets and short filaments, I. packets and settled zoospores.

Halofilum salinum (Dangeard) Darienko et Pröschold comb. nov. (Fig. 10A)

Basionym: Heterogonium salinum Dangeard 1911, Bull. Soc. Bot. France 58: 311, fig. 1.

Synonym: Pirula salina (Dangeard) Printz 1927, Chlorophyceae in Engl. Natürl. Pflanzenfam. 225.

Diagnosis: Filaments are short, usually not more than 2-4 cells. The filaments are very fragile and easily disintegrated. They can be observed only in very young cultures (not older than several days). Cells are pear-shaped with a relatively thick cell wall. The chloroplast is parietal and usually covers $2 / 3$ of the cell. The pyrenoid is present and surrounded by 2-4 large starch grains. Mature vegetative cells are 6.0-12.0 $\mu \mathrm{m}$ long $\times 5.0-9.0 \mu \mathrm{m}$ wide and are uninucleate. Reproduction occurs by budding. Young cells are approximately $4.0 \mu \mathrm{m} \times 3.0 \mu \mathrm{m}$.

Differs from other species by SSU-ITS sequences and reproduction by budding. 


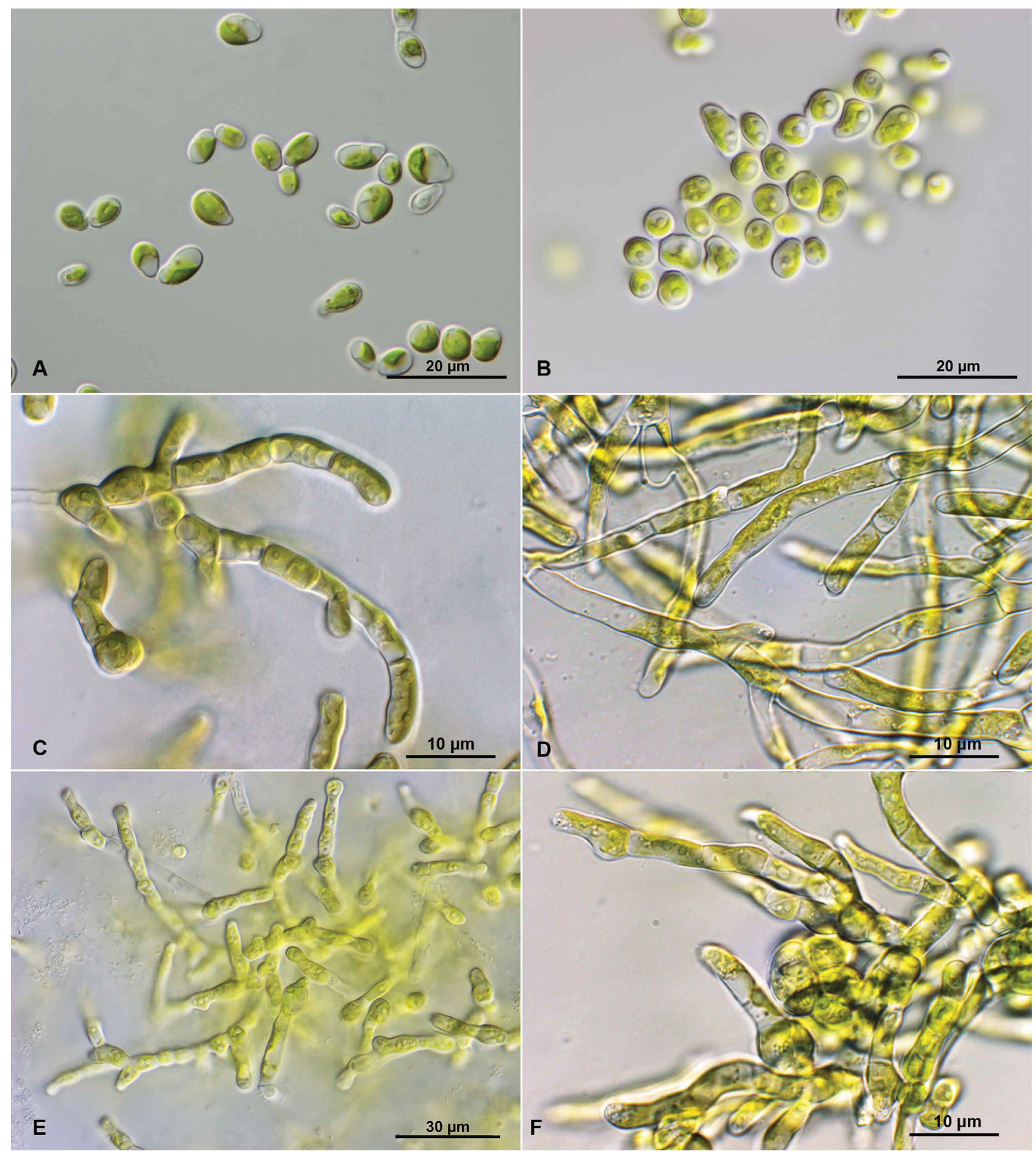

FIGURE 10. Overview about the morphology of the investigated Halofilum strains grown on SWES medium. A. H. salinum SAG 1.95, B. H. helgolandicum SAG 2.95, C. H. ramosum SAG 2050, D. H. ramosum SAG 2235; E. H. ramosum ULVO-19, F. ULVO-28.

Habitat: unknown

Type locality: unknown (only known from a culture vessel containing sea water).

Lectotype (designated herein): Fig. 1 in Dangeard (1911).

Epitype (designated herein): The strain SAG 1.95 is permanently cryopreserved in a metabolically inactive state (cryopreserved in liquid nitrogen) in the SAG, University of Göttingen, Germany.

ITS-2 DNA Barcode: HAL1 in Figs S2.

Comment: The formation of short filaments was observed only on SWES agar plates under an inverted microscope. The filaments are very fragile and immediately disintegrate by preparation on a microscopy slide. 
Halofilum helgolandicum Darienko et Pröschold sp. nov. (Fig. 11A-C)

Diagnosis: Filaments are very short, usually not more than $2-8$ cells. The filaments are branched, very fragile and easily disintegrate. They can be observed only in very young cultures (not older than several days). After one week of cultivation on the fresh medium, they occur as solitary cells. Cells are pear-shaped with a relatively thick cell wall. The chloroplast is parietal and usually covers $2 / 3$ of the cell. The pyrenoid is present and surrounded by $2-4$ large starch grains. Single vegetative cells are $8.0-10.0 \mu \mathrm{m}$ long $\times 5.0-6.0 \mu \mathrm{m}$ wide and uninucleate. Vegetative cells of filaments sometime can reach 14.0-20.0 $\mu \mathrm{m} \times 4.5-5.0 \mu \mathrm{m}$. Reproduction occurs by budding.

Differs from other species by SSU-ITS sequences and reproduction by budding.

Habitat: from an enrichment culture of Rhizoclonium riparium.

Type locality: Heligoland, Germany.

Holotype (designated herein): The strain SAG 2.95 is permanently cryopreserved in a metabolically inactive state (cryopreserved in liquid nitrogen) in the SAG, University of Göttingen, Germany.

Iconotype (designated herein in support of the holotype): Fig. 11B in this study.

ITS-2 DNA Barcode: HAL2 in Figs S2.

\section{Halofilum ramosum Darienko et Pröschold sp. nov. (Fig. 11D-G)}

Diagnosis: Filaments are relative long, consisting of 20-100 cells, richly branched and curved. The cells of primary branches are slightly shorter, equal to or to twice as long as broad; cylindrical or square; $7.8-12.5 \mu \mathrm{m}$ long $\times 6.9-8.5 \mu \mathrm{m}$ wide. The secondary branches appear laterally or bilateral. The terminal cells of secondary branches are cylindrical, often pointed, up to 5 times longer as broad. Cells are 16.0-28.0 $\mu \mathrm{m}$ long $\times 5.6-7.2 \mu \mathrm{m}$ wide. The longest terminal cells very often contain $2-3$ pyrenoids and nuclei. Such cells probably represent some special stage of vegetative dividing. In the primary filaments, irregular cells containing up to 4 pyrenoids were observed. The cells later formed package-like structures, and from these cells the secondary branches often arise. Reproduction by budding or by zoospores was not observed.

Differs from other species by SSU-ITS sequences and the absence of reproduction by budding.

Habitat: marine, photobiont of Wahlenbergiella striatula.

Type locality: Wales, Anglesey (Ynys Mon), Porth Trecastel, in stone cracks of coastal rocks.

Holotype (designated herein): The strain SAG 2050 is permanently cryopreserved in a metabolically inactive state (cryopreserved in liquid nitrogen) in the SAG, University of Göttingen, Germany.

Iconotype (designated herein in support of the holotype): Fig. $11 \mathrm{~F}$ in this study.

ITS-2 DNA Barcode: HAL3a/b in Figs S2.

Comment: This species is probably widely distributed as photobiont and free-living. Additional strains: SAG 2235 and ULVO-28 were isolated from Verrucaria maura, Roscoff, Brittany, France and ULVO-19 was isolated from a green crust on the wall of ruins in Carthage, Tunisia (see Hoffmann \& Darienko 2010).

Note: The budding-like reproduction of Halofilum is quite rare among microalgae and has only been reported for few green algal genera, which belong to the Trebouxiophyceae (Pseudomarvania, Eliaš \& Neustupa 2009; Marvania, Nannochloris, Yamamoto et al. 2007).

\section{Ctenocladus versus Lochmiopsis}

The genus Ctenocladus described by Borzi (1883) is from a marine habitat. The characteristic morphological feature of the type species C. circinnatus is the one-sided branching of the filaments. Ctenocladus is so far known as a rare species. Only few records have been published (Blinn \& Stein 1970; Herbst \& Castenholz 1994). Only one strain of C. circinnatus has been isolated and deposited in a public culture collection (CCMP 2158). However, this strain does not show the typical morphology of this genus in culture. In our study, this strain is almost identical in sequences with strains that were isolated from sandstone, and salt marshes at high carbonate concentrations (solonetz-solonchak). The latter habitat is typical for the genus Lochmiopsis, which was described by Woronichin \& Popova (1929) from soda lakes in Siberia (Russia). This genus was also recorded from solonetz-solonchak soils in different Asian deserts (Novichkova-Ivanova 1984). Ruinen (1933) has demonstrated that L. sibirica has high phenotypic and ecological plasticity. She showed that material from the type locality and from California has similar morphology and ecology. Based on her findings, Smith (1950) transferred this genus Lochmiopsis as a later synonym of Ctenocladus, which is currently accepted by most phycologists (Blinn \& Stein 1970). Our investigations showed similarities and differences in morphology and ecology to those of both genera. Unfortunately, no authentic material of both genera are available in culture collections. Therefore, the taxonomic status remains unclear. However, as our study has demonstrated the type strain of Pseudopleurococcus printzii is closely related to the investigated strains mentioned above. As a consequence, 
we propose as a compromise the usage of the generic name Ctenocladus until material of both genera collected from type localities has been investigated.

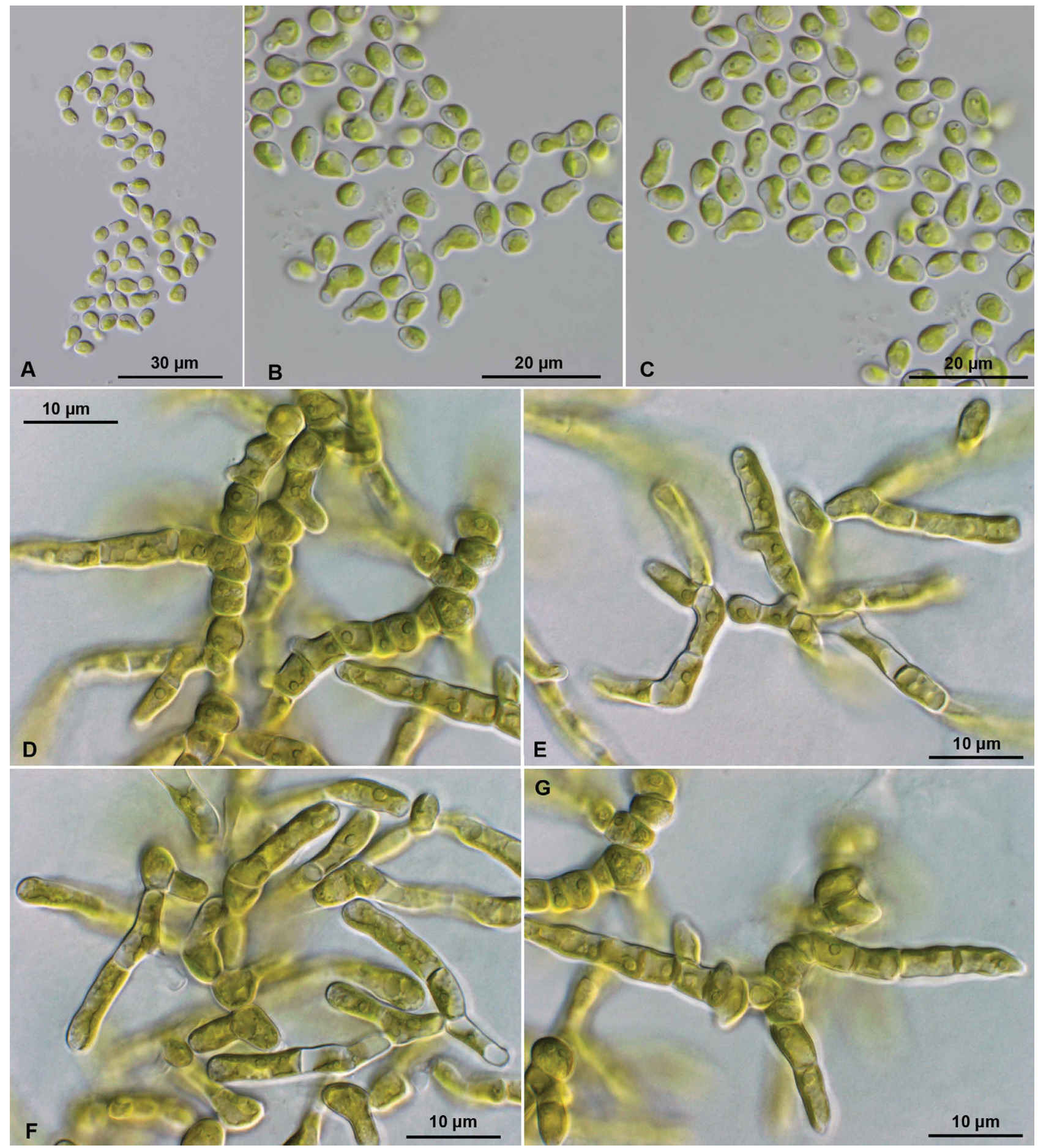

FIGURE 11. Morphology of A-C. Halofilum helgolandicum SAG 2.95 and D-G. H. ramosum SAG 2050 grown on 1/2SWES medium.

Ctenocladus Borzi 1883, Studi Algologici I: 27-50.

Investigated strains: CCMP 2158, SAG 467-1, ULVO-16, ULVO-17, ULVO-18, ULVO-24, ULVO-25 (Figs $12-13)$.

Ctenocladus circinnatus Borzi 1883, Studi Algologici I: 27-28 (diagnosis latina), figs. 3: 1-10, 4: 11-20. (Fig. 12A-J, $13 \mathrm{~A}-\mathrm{E})$

Lectotype (designated herein): Fig. 4: 12 in Borzi (1883).

Epitype (designated herein): The strain CCMP 2158 is permanently cryopreserved in a metabolically inactive state (cryopreserved in liquid nitrogen) in the CCMP, USA. 


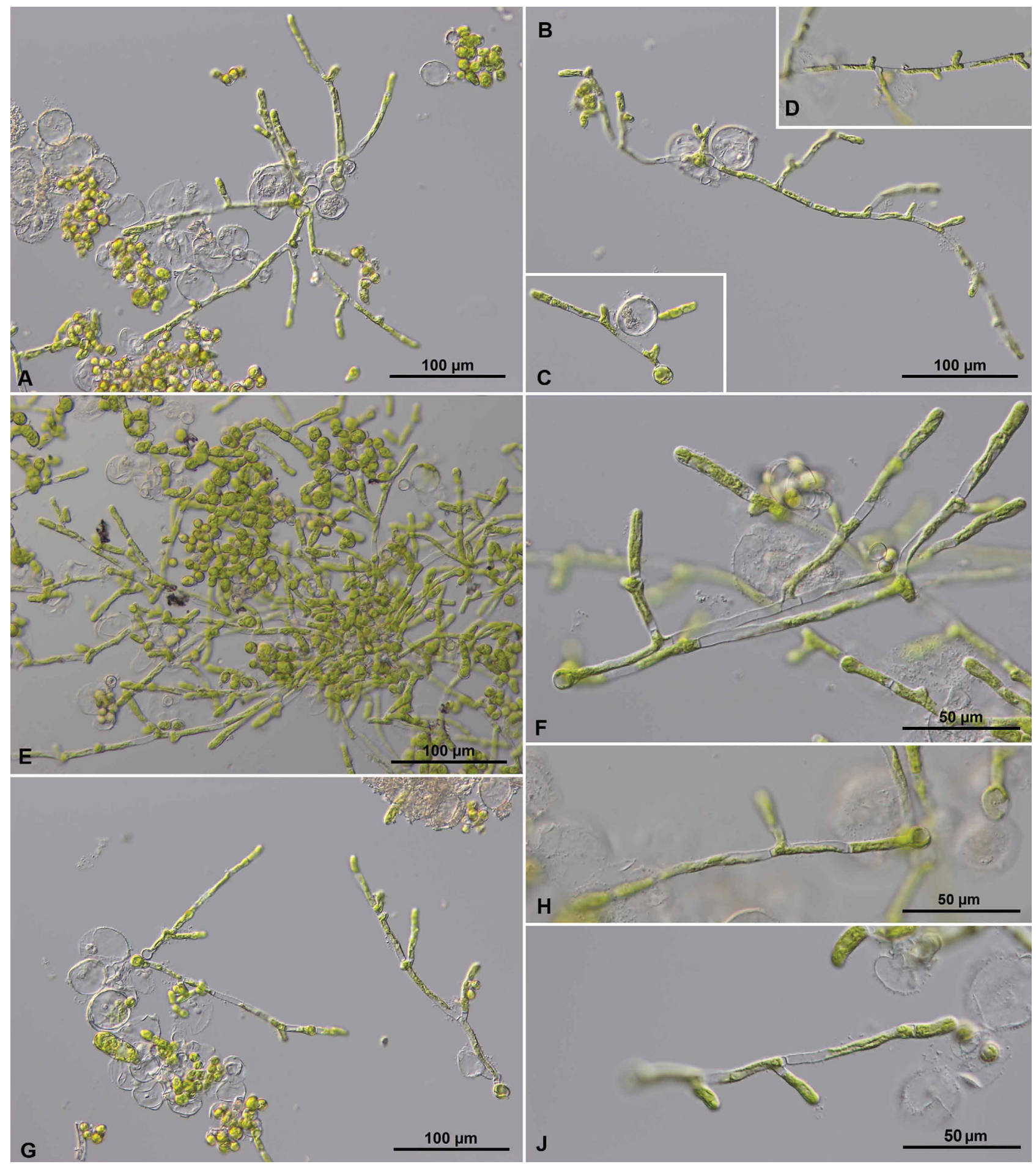

FIGURE 12. Morphology of Ctenocladus circinnatus CCMP 2158 grown on 1/2SWES medium, two-weeks old cultures.

ITS-2 DNA Barcode: CTE1 in Figs S2.

Comment: This species is probably widely distributed in soils under Salicornia prostrara with sulfate-chloride solonchaks and sulfate solonetz (ULVO-15, ULVO-16, ULVO-49) and epilithic on sandstone (ULVO-18 and CCMP 2158) and silicates (ULVO-24). The same algae was likely observed by Novichkova-Ivanova (1984) on solonchaks soil in the Middle East and identified under the name Lochmiopsis sibirica Woron. et Popova.

Ctenocladus printzii (Vischer) Darienko et Pröschold comb. nov. (Fig. 13F)

Basionym: Pseudopleurococcus printzii Vischer 1933, Beih. Bot. Centralbl. 51/I: 34-35 (diagnosis latina), figs 11: 1-11, 12:1-8.

Synonym: Dilabifilum printzii (Vischer) Tschermak-Woess 1970, Österr. Bot. Z. 118: 452. 


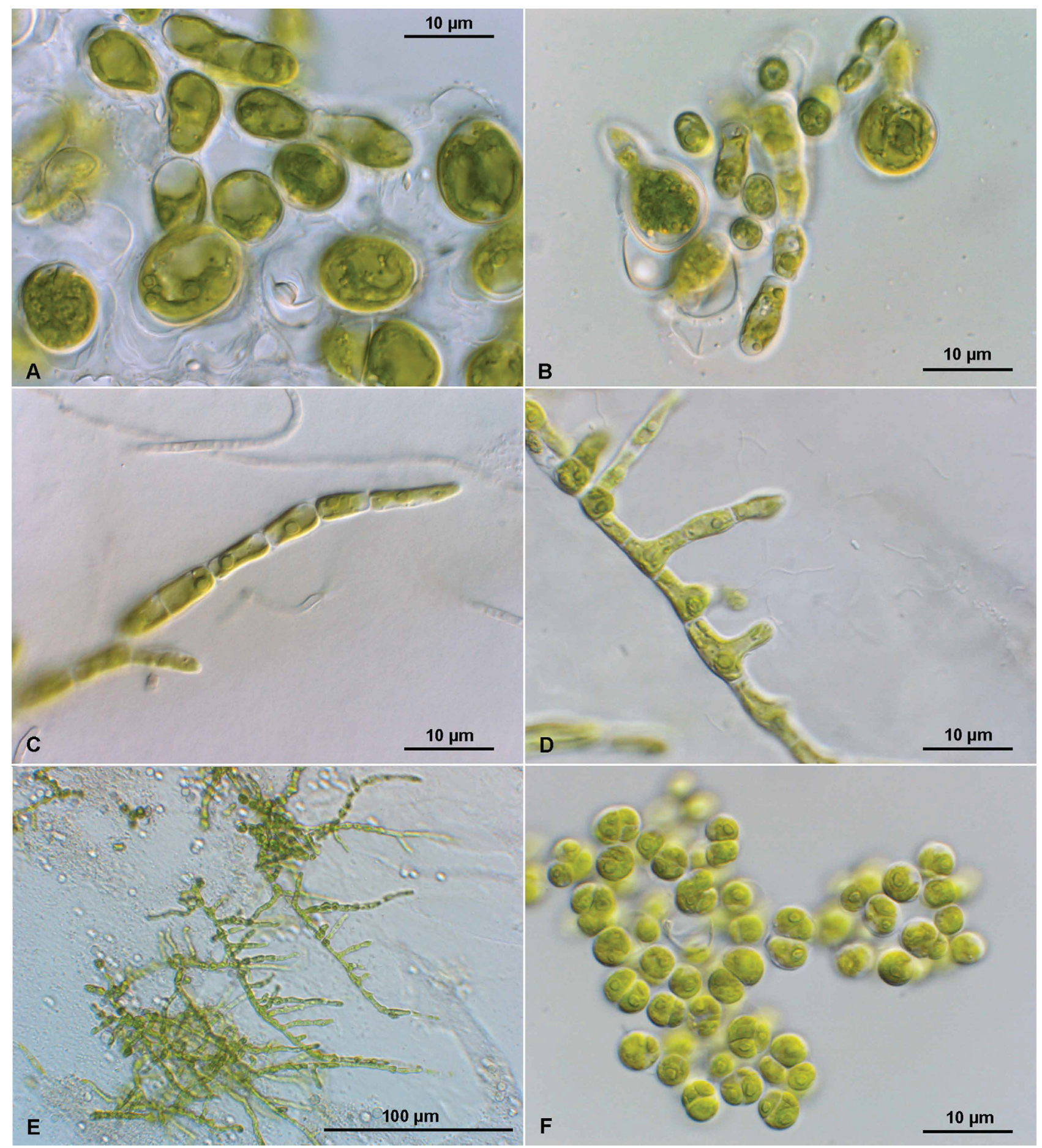

FIGURE 13. Overview about the morphology of the investigated Ctenocladus strains grown on 3NBBM medium. A,B. ULVO-16, C. ULVO-18, D,E. ULVO-24, F. SAG 467-1.

Lectotype (designated herein): Fig. 11: 3 in Vischer (1933).

Epitype (designated herein in support of iconotype): The authentic strain SAG 467-1 is permanently cryopreserved in a metabolically inactive state (cryopreserved in liquid nitrogen) in the SAG, University of Göttingen, Germany.

ITS-2 DNA Barcode: CTE2 in Figs S2. 


\section{The order Ulotrichales sensu Mattox and Stewart}

\section{The genus Trichosarcina}

The genus Trichosarcina was described by Nichols \& Bold (1965) from shallow pool in granite rocks at Enchanted Rock and Balanced Rock in Texas. The algae is characterized by initial uniserial filaments become pluriserial with time. The other interesting peculiarity is zoosporogenesis. Only one quadriflagellated zoospore was produced per vegetative cell. Unfortunately, the name T. polymorpha is invalid because the type was not designated, and generic and species were described in one diagnosis (descriptio generico-specifica, Art. 38.5, ICN). Chappell \& O`Kelly (1991) performed the ultrastructural investigation of Pseudoschizomeris mucosa Broady and discovered that this alga belong to the genus Trichosarcina (T. mucosa (Broady) Chappell et O'Kelly). Thompson \& Wujek (1996) transferred both species to Filoprotococcus Kufferath with the type species Filoprotococcus enteromorphoides Kufferath, which was originally found in lotic water in Luxembourg. They found this alga in the marshy area near Kansas (USA) as an epiphyte growing on Tolypella nidifica var. glomerata. The authors highlighted that this alga has some clear differences in comparison to T. polymorpha, which are two times larger in cell size and produce 2-4 zoospores per cell. Unfortunately, no information about the number of flagella was provided. Other differences between both genera are the absence of a pyrenoid in Filoprotococcus.

We studied several isolates, including the authentic strains of Trichosarcina polymorpha and T. mucosa. All strains are morphologically very similar and have almost identical SSU and ITS rDNA sequences, thus belonging to one species. Unfortunately, the genus Trichosarcina has not been validly described, and consequently all later combination are also invalid. For a valid publication of genera and species described according to Art. 38.5, three criteria have to be fulfilled. Whereas the first two criteria have been satisfied (monotypic genus at the time of publication, new species, not no combination), the last about the clear typification has not been clarified in Nichols \& Bold (1965). Then on or after $1^{\text {st }}$ January 1958 of the name of a new taxon of the rank of genus or below is valid only when the type of the name is indicated (Art. 40.1, ICN). Nichols \& Bold (1965) investigated this species from two collections (1960 and 1961), but they did not designate any of the two as type. Therefore, this genus and species is invalid. As a consequence, we propose the following new genus.

Sarcinofilum Darienko et Pröschold gen. nov.

Synonym: Trichosarcina Nichols et Bold 1965, J. Phycol. 1: 38 (diagnosis latina) (nom. invalid)

Diagnosis: Young filaments are uniserial and contain short cylindrical cells. Uniserial filaments contain 20-30 cells and are usually detached from the substrate. Vegetative cells contain parietal chloroplasts with a single pyrenoid and nucleus. The pluriserial filaments develop uniserially through several longitudinal divisions in perpendicular directions that result in the formation of sarcinoid-like three-dimensional structures. The pluriserial filaments can reach hundreds of cells, and then start to disintegrate into packages and become free-floating entities.

Asexual reproduction occurs through fragmentation of the filaments or special zoosporogenesis. Quadriflagellated zoospores develop into the vegetative cells of pluriserial filaments. Each cell forms only one zoospore.

Sexual reproduction is not observed.

The phylogenetically closely related genera differ by presence of pluriserial filaments and by differences in SSUITS sequences.

Type species (designated herein): Sarcinofilum mucosum (Broady) Darienko et Pröschold comb. nov.

Investigated strains: SAG 4.90, SAG 24.93, SAG 26.88, SAG 26.94, SAG 29.94 (Fig. 14).

Sarcinofilum mucosum (Broady) Darienko et Pröschold comb. nov. (Fig. 14A-F)

Basionym: Pseudoschizomeris mucosa Broady 1982, Nova Hedwigia 36: 468 (diagnosis latina), figs 105-116, 132-140 (holotype).

Synonym: Trichosarcina mucosa (Broady) Chappell et O‘Kelly 1991, Crypt. Bot. 2: 253, Trichosarcina polymorpha Nichols et Bold 1965, J. Phycol. 1: 38 (diagnosis latina) (nom. invalid), Filoprotococcus polymorphus (Nichols et Bold) Thompson et Wujek 1996 (nom. invalid)

Epitype (designated herein in support of the holotype): The strain SAG 4.90 is permanently cryopreserved in a metabolically inactive state (cryopreserved in liquid nitrogen) in the SAG, University of Göttingen, Germany.

ITS-2 DNA Barcode: SAR1a/b in Figs S2. 


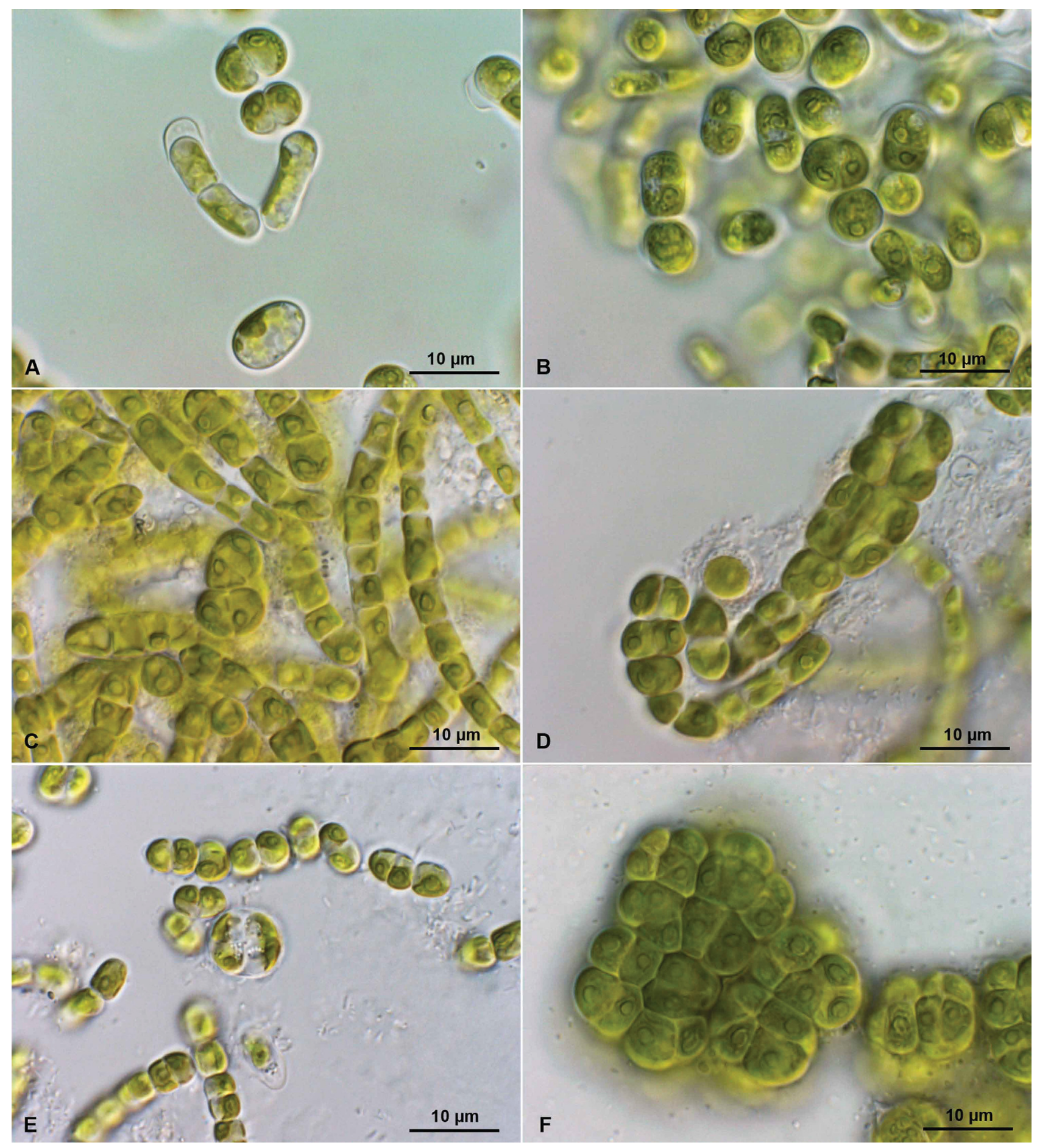

FIGURE 14. Overview about the morphology of the investigated Sarcinofilum strains grown on 3NBBM medium. A,B. SAG 4.90, C. SAG 24.93, D. SAG 29.94, E. 26.94, F. SAG 26.88.

\section{The genera Planophila Gerneck and Pseudendocloniopsis Vischer}

The genus Planophila (with its type species P. laetevirens) was described by Gerneck (1907) from soil sample with moss protonema. Later, several more species of this genus were proposed. Reisigl (1964) described Planophila bipyrenoidosa from alpine chalk soils. This alga differs from the type species by having a smaller cell size and containing 1-3 pyrenoids. P. terrestris was described by Groover \& Hofstetter (1969). Broady (1982) isolated two strains of Planophila A and B from Iceland and Antarctica, respectively. Dangeard (1965) described a new species Ulvella microcystoides, which was later transferred to Planophila by Kornmann \& Sahling (1983). 
Friedl \& O'Kelly (2002) revised the genus Planophila based on SSU phylogeny and TEM. They confirmed that Planophila laetevirens is a member of Ulvophyceae and is not close related to the Planophila A and B of Broady. Planophila A was transferred to the newly erected genus Pabia by Friedl \& O'Kelly (2002), and was later synonymized with Pseudochlorella by Darienko et al. (2016). Friedl \& O'Kelly (2002) also discovered that Planophila terrestris is a member of the Chloropeltidales and established a new genus Floydiella. They also proposed a new genus Dangemannia for Planophila microcystoides, which was later corrected as Neodangemannia by Wynne \& Funari (2014).

Friedl \& O'Kelly (2002) also discovered that the monotypic genus Pseudendocloniopsis (type species: P. botryoides), which was described by Vischer (1933), is closely related to Planophila. Printz (1964) transferred the genus Filoprotococcus to Pseudendocloniopsis; however, this combination is invalid because the name Filoprotococcus is older.

In our study, we investigated seven strains that could be clearly identified as $P$. laetevirens and $P$. bipyrenoidosa. For both species, we proposed the following lectotypes and epitypes.

Planophila Gerneck 1907, Beih. Bot. Centralbl. 21: 227-228.

Investigated strains: SAG 2008, SAG 32.98, SAG 465-1, ULVO-1, ULVO-55, GSM-5A-LK1 (Fig. 15).

Planophila laetevirens Gerneck 1907, Beih. Bot. Centralbl. 21: 227-228, fig. 9 (4-6).

Synonym: Pseudendocloniopsis botryoides Vischer 1933, Beih. Bot. Centralbl. 51/I: 28, figs 9, 10.

Lectotype (designated herein): Fig. 9 (4-6) in Gerneck 1907.

Epitype (designated herein): The strain SAG 2008 is permanently cryopreserved in a metabolically inactive state (cryopreserved in liquid nitrogen) in the SAG, University of Göttingen, Germany.

Comment: Widely distributed species.

ITS-2 DNA Barcode: PLA1a/b in Figs S2.

Planophila bipyrenoidosa Reisigl 1964, Österr. Bot. Z. 111: 478 (diagnosis latina), fig. 33 (iconotypus) (Fig. 15AQ)

Epitype (designated herein): This strain ULVO-55 is permanently cryopreserved in a metabolically inactive state (cryopreserved in liquid nitrogen) in the SAG, University of Göttingen, Germany.

ITS-2 DNA Barcode: PLA2a/b in Figs S2.

\section{Rhexinema versus Pleurastrum and Gloeotilopsis}

The genus Rhexinema was described by Geitler (1942) to separate Pleurastrum paucicellulare from other species of this genus based on the following morphological criteria: very short branched filaments that easily disintegrate, parietal chloroplasts with a pyrenoid, and biflagellated zoospores. P. paucicellulare was originally described by Vischer (1933) from neustons in stagnant water near Basel, Switzerland (authentic strain SAG 463-1). Tupa (1974) did not support Rhexinema and left this species with Pleurastrum, in contrast to Lukešová (1991) and Ettl \& Gärtner (1995), who accepted the genus as described by Geitler.

Friedl (1996) used phylogenetic analyses of SSU rDNA sequences to determine the polyphyly of the genus Pleurastrum and demonstrated the close relationship of Pleurastrum paucicellulare (SAG 463-1) with Protoderma sarcinoidea (UTEX 1710) and Gloeotilopsis planctonica (SAG 29.93). On this basis, he proposed the new combinations of Gloeotilopsis paucicellulare and G. sarcinoidea. Unfortunately, as demonstrated in our study, the identification of the strain SAG 29.93 was incorrect and did not fit with the original description by Iyengar \& Philipose (1956). Therefore, all other combinations with Gloeotilopsis must be changed. Despite the different opinions about the genus Rhexinema by Tupa (1974), Geitler's proposal was based on the authentic material of Vischer for Pleurastrum paucicellulare. Therefore, the genus Rhexinema has been validly described, and we proposed the following new combinations and species. Interestingly, several strains assigned as species of other genera also belong to Rhexinema. The authentic strain of Pseudendoclonium basiliense var. brandii and a strain identified as Helicodictyon planctonica are also members of Rhexinema. Both strains exhibit a morphology similar to their original descriptions by Vischer (1933) and Whitford \& Schumacher (1966), as demonstrated in our study. 


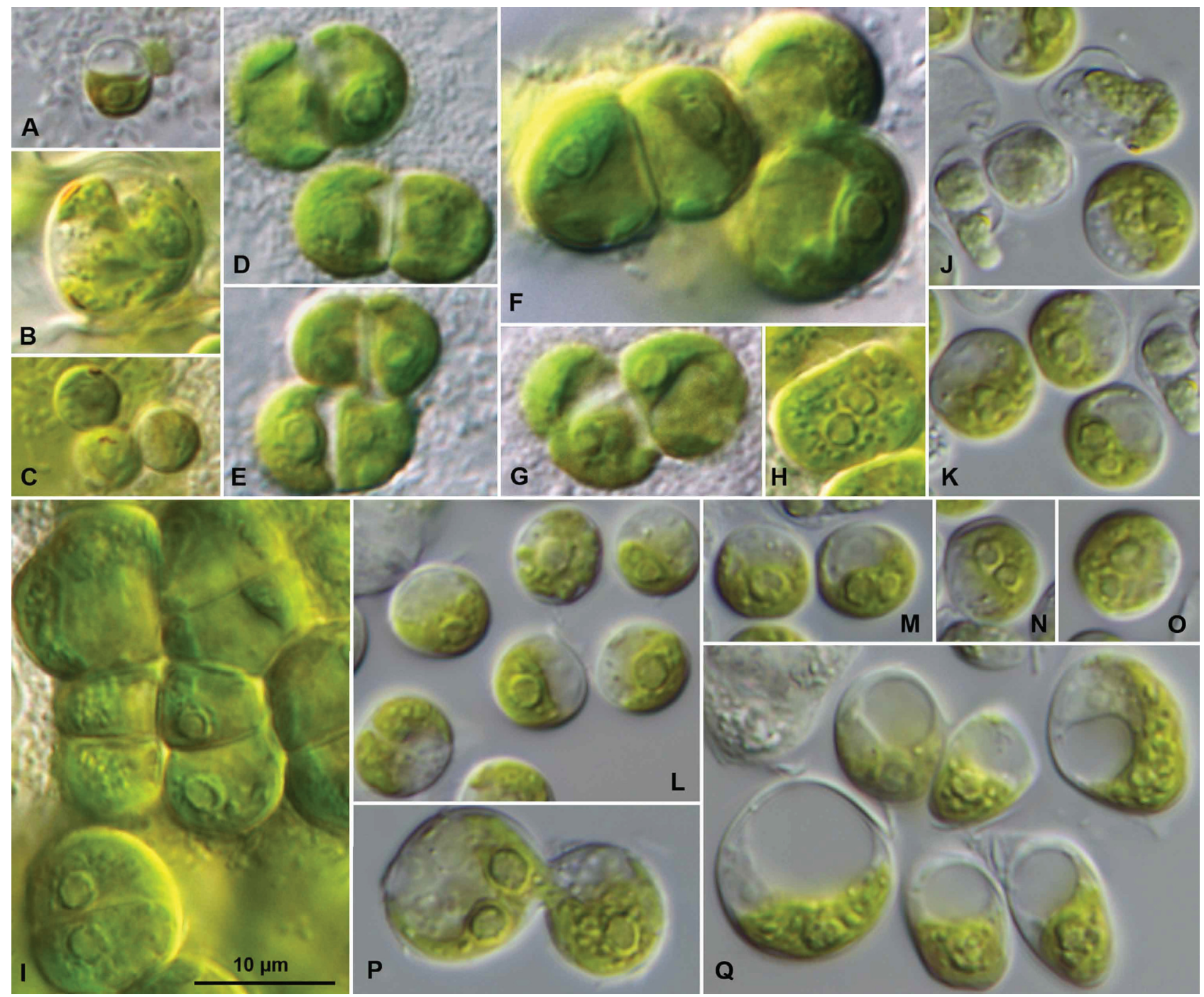

FIGURE 15. Morphology of Planophila bipyrenoidosa A-I. ULVO-1 and J-Q. ULVO-55 grown on 3NBBM medium. A-C. settled zoospores and sporangium, D-I. cell packets, J. settled zoospores, $\mathbf{K}-\mathbf{Q}$. variety of vegetative cells.

Rhexinema Geitler 1942, Biol. Gen. 16: 473 (diagnosis latina).

Emended diagnosis: The filaments are very short consisting of 2-10 cells or 2-dimensional cell packages embedded in common mucilage. Branching is rudimentary. Vegetative cells are cylindrical, often curved, and uninucleate, with a parietal chloroplast containing one pyrenoid surrounded by starch grains. Reproduction occurs by vegetative division, and biflagellated zoospores possess a stigma and two contractile vacuoles.

Investigated strains: ACOI 592, SAG 463-1, SAG 466-2, SAG 29.93, SAG 8.90, UTEX 1570, UTEX 1710, ULVO-10 (Figs 16-20).

Rhexinema paucicellularis (Vischer) Geitler 1942, Biol. Gen. 16: 473. (Fig. 16A-D)

Basionym: Pleurastrum paucicellulare Vischer 1933, Beih. Bot. Centralbl. 51/I: 21 (diagnosis latina), figs 4.

Synonym: Gloeotilopsis paucicellulare (Vischer) Friedl 1996, Phycologia 35: 466, Gloeotilopsis planctonica sensu Sluiman 1991, non Gloeotilopsis planctonica Iyengar et Philipose 1956, Pseudendoclonium basiliense var. brandii Vischer 1933, Beih. Bot. Centralbl. 51/I: 24 (diagnosis latina), figs 6 1-7,7 1-4.

Lectotype (designated herein): Fig. 4 in Vischer (1933).

Epitype (designated herein in support of the lectotype): The strain SAG 463-1 is permanently cryopreserved in a metabolically inactive state (cryopreserved in liquid nitrogen) in the SAG, University of Göttingen, Germany.

ITS-2 DNA Barcode: RHE1 in Figs S2. 


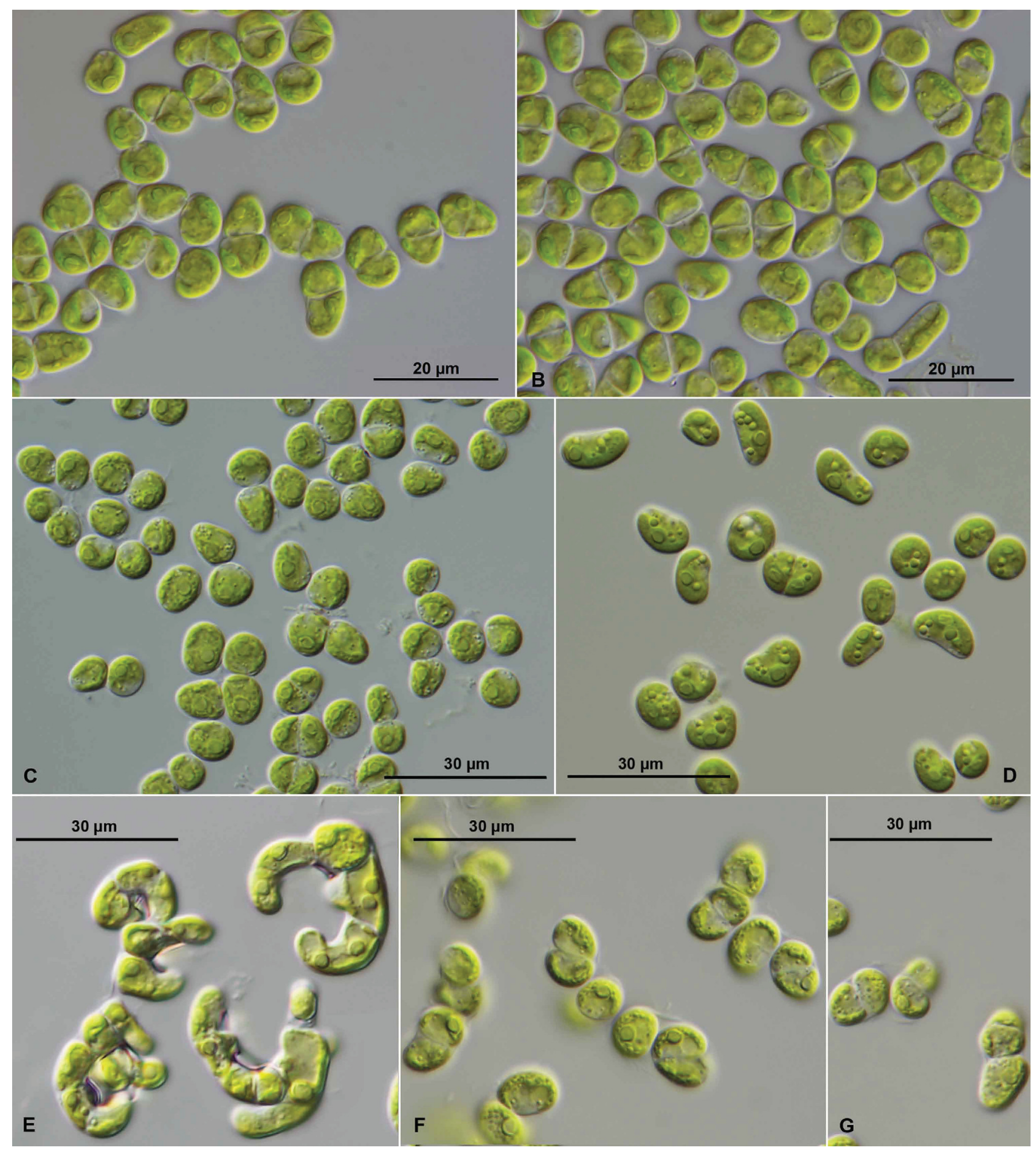

FIGURE 16. Overview about the morphology of the investigated Rhexinema strains grown on MiEB12 medium. A. R. paucicellularis SAG 463-1, B. SAG 29.93, C. SAG 8.90, D. SAG 466-2; E. R. planctonica UTEX 1570, F,G. R. sancta-tomea ACOI 592.

Rhexinema sarcinoidea (Groover et H.C.Bold) Darienko et Pröschold comb. nov. (Fig. 17A-F)

Basionym: Pleurastrum sarcinoideum Groover et H.C.Bold 1969, Phycol. Stud. VIII: 51 (diagnosis latina), figs 37, 150-158, 15932.

Synonym: Protoderma sarcinoidea (Groover et Bold) Tupa 1974, Beih. Nova Hedwigia 46: 3; Gloeotilopsis sarcinoidea (Groover et Bold) Friedl 1996, Phycologia 35: 466.

Epitype (designated herein in support of the holotype): The strain UTEX 1710 is permanently cryopreserved in a metabolically inactive state (cryopreserved in liquid nitrogen) in the SAG, University of Göttingen, Germany.

ITS-2 DNA Barcode: RHE2 in Figs S2. 


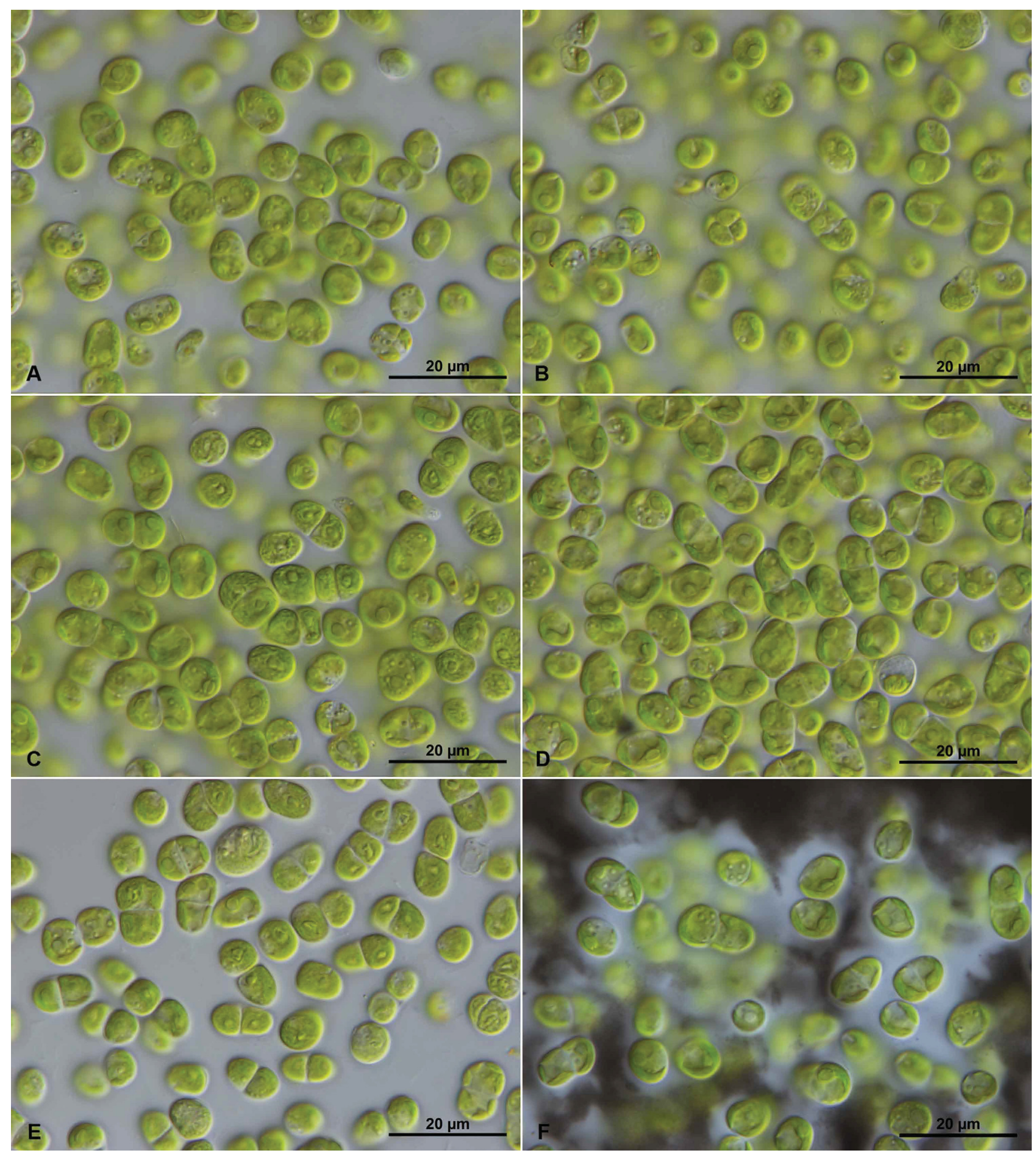

FIGURE 17. Morphology of Rhexinema sarcinoidea UTEX 1710 grown on MiEB12 medium.

Rhexinema planctonica (Whitford) Darienko et Pröschold comb. nov. (Fig. 16E, 18A-H)

Basionym: Heterodictyon planctonicum Whitford 1956, Trans. Am. Micro. Soc. 75: 201 (diagnosis latina), figs. 12-15 (nom. invalid), Heterodictyon planctonicum Whitford 1960, Trans. Am. Micro. Soc. 79: 228 (emended diagnosis), fig. 8-10 (nom. invalid).

Synonym: Helicodictyon planctonicum (Whitford) Whitford et Schumacher 1966, Phycologia 5: 274.

Lectotype (designated herein): Fig. 13 in Whitford (1956).

Epitype (designated herein): The strain UTEX 1570 is permanently cryopreserved in a metabolically inactive state (cryopreserved in liquid nitrogen) in the UTEX, University of Texas, USA.

ITS-2 DNA Barcode: RHE3 in Figs S2.

Comment: Biebel (1968) isolated the strain UTEX 1570, which we have investigated in this study. The morphology 
of this strain is consistent with the original description by Whitford $(1956,1960)$ and Whitford \& Schumacher (1966).

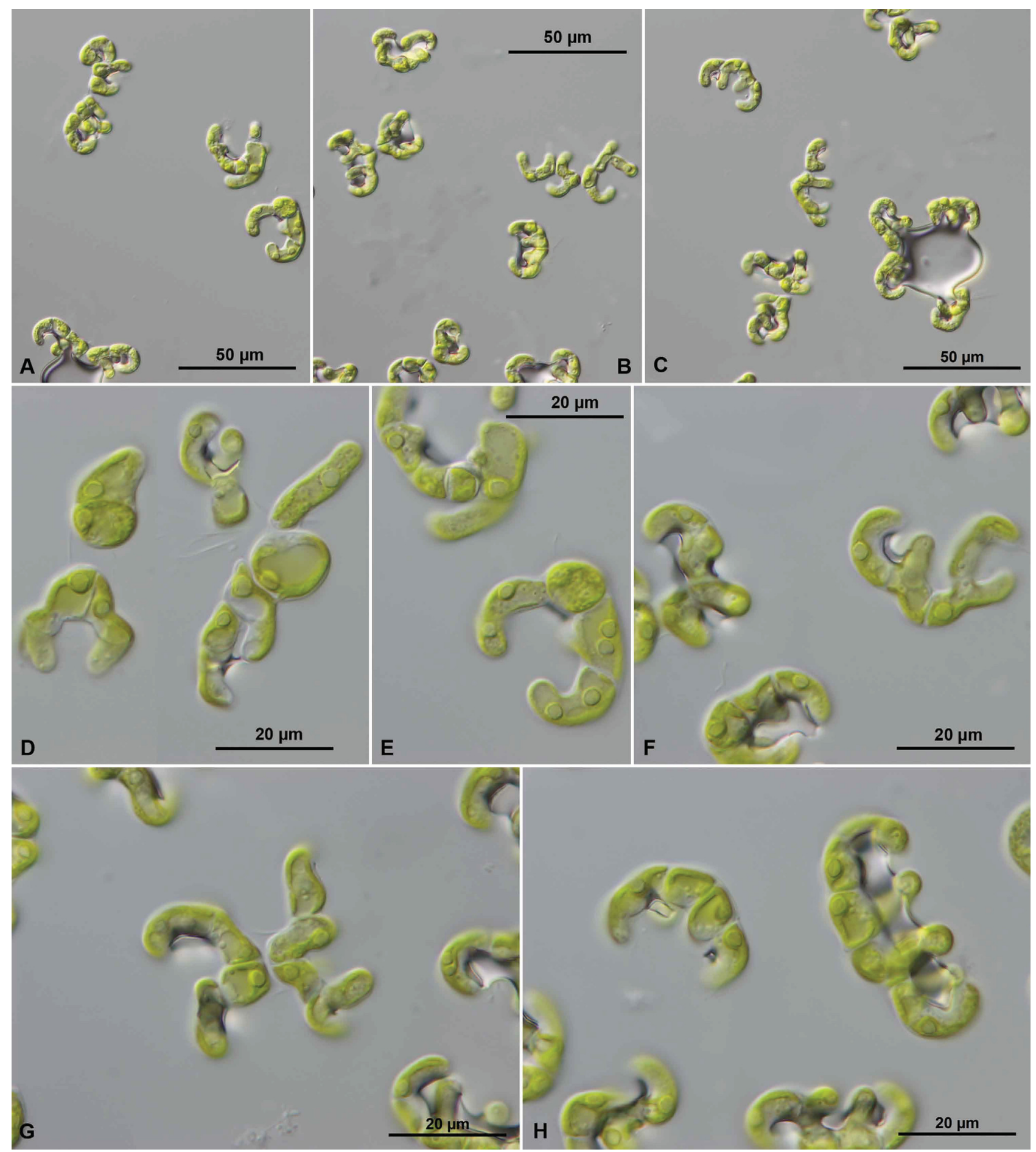

FIGURE 18. Morphology of Rhexinema planctonica UTEX 1570 grown on MiEB12 medium.

Rhexinema edaphica Darienko, Pröschold et Lukešová sp. nov. (Fig. 19A-G)

Diagnosis: Algae occurs as solitary cells, short 2-4-celled filaments or forms 2-4 packages surrounded by mucilage. The branching is very rudimentary and rare. Single cells are oval, and approximately 6.0-7.0 $\mu \mathrm{m}$ in diameter. Cells in packages are compressed from the sides, and are 5.0-10.0 $\mu \mathrm{m}$ long $\times 5.0-8.5 \mu \mathrm{m}$ wide. Cells are uninucleate, with parietal chloroplasts, containing one good visible pyrenoid surrounded by several starch grains. Reproduction occurs by vegetative division. Zoospores are not observed.

Other species of Rhexinema differ by a Chlorosarcinopsis-like morphology and by SSU-ITS sequences.

Habitat: lateritic soil. 


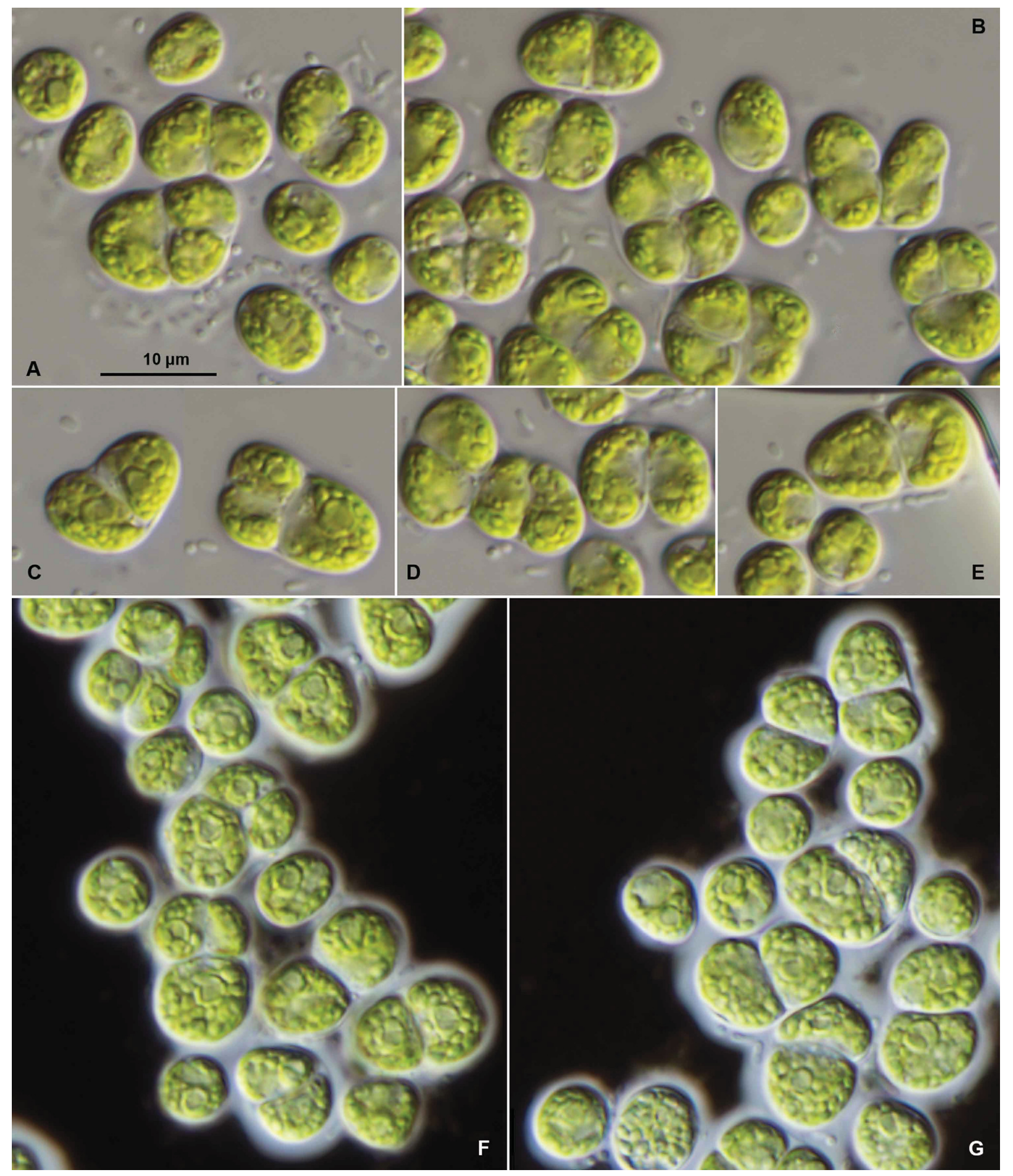

FIGURE 19. Morphology of Rhexinema edaphica ULVO-10 grown on MiEB12 medium. A-E. cells packets and rudimentary branching, F,G. single cells and packets surrounded by common mucilage contrasted by indian ink.

Type locality: Brazil, central part of Sao Paulo State, Sao Carlos, Itirapina and Pirissanunga County, elevation of about $800 \mathrm{~m}$ a.s.l., field of sugar cane, dense canopy, without any ground layer.

Holotype (designated herein): The strain ULVO-10 is permanently cryopreserved in a metabolically inactive state (cryopreserved in liquid nitrogen) in the SAG, University of Göttingen, Germany.

ITS-2 DNA Barcode: RHE4 in Figs S2. 
Rhexinema sancta-tomea Darienko et Pröschold sp. nov. (Fig. 16F-G, 20A-G)

Diagnosis: Algae occurring as short 2-8-celled curved filaments, solitary or forming pseudofilaments of 2celled packages held together by the remaining old cell walls. The cells are embedded in mucilage. Branching is very rudimentary and rare. The end cells of the rudimentary branches are ovoid or pear-shaped. Single cells are ovoid, oval or round with a diameter of 8.0-9.3 $\mu \mathrm{m}$. Cells in packages are compressed from the sides, and have a diameter of $8.0-11.3 \mu \mathrm{m}$. End cells of rudimentary branches are $11.5 \mu \mathrm{m} \times 8.0 \mu \mathrm{m}$. Cells are uninucleate with parietal chloroplasts containing one good visible pyrenoid surrounded by several starch grains. Reproduction occurs by vegetative division. Zoospores are not observed.

Other species of Rhexinema differ by SSU-ITS sequences.

Habitat: Mud.

Type locality: São Tomé and Príncipe.

Holotype (designated here): The strain ACOI 592 is permanently cryopreserved in a metabolically inactive state (cryopreserved in liquid nitrogen) in the SAG, University of Göttingen, Germany.

ITS-2 DNA Barcode: RHE5 in Figs S2.
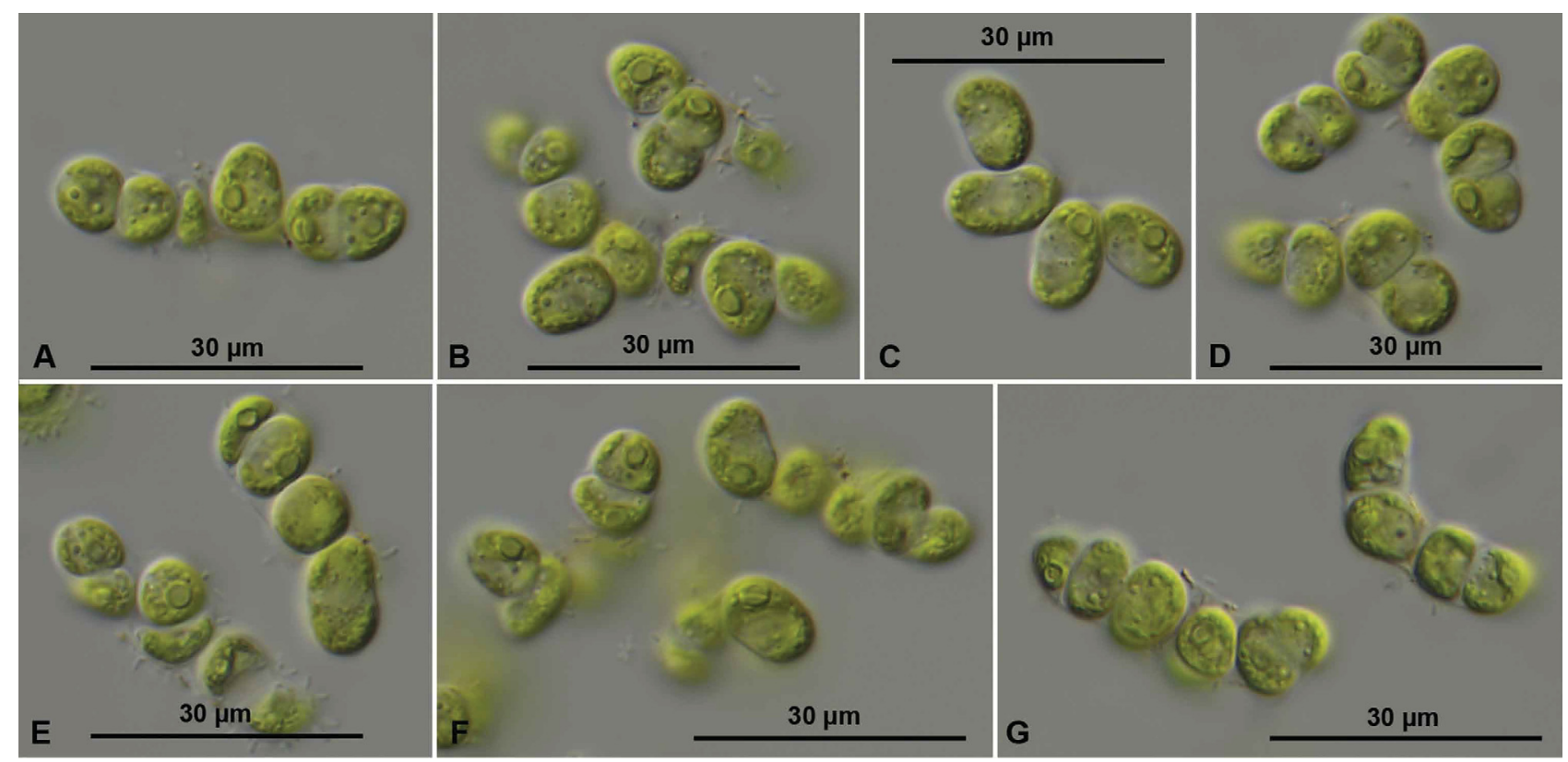

FIGURE 20. Morphology of Rhexinema sancta-tomea ACOI 592 grown on MiEB12 medium.

\section{Hazenia versus Chamaetrichon}

The genus Hazenia (with the type species H. mirabilis) was described by Bold (1958) from a pool at Couchville Pike, Tennessee. This alga is characterized by short, irregularly branched filaments surrounded by mucilage. The cells are short and cylindrical with parietal chloroplasts containing pyrenoids with several starch grains. Asexual reproduction occurs through fragmentation of filaments. Sexual reproduction occurs by biflagellated isogametes. Zygotes with multilayered cell walls were also observed. Skaloud et al. (2013a) described a new species, H. broadyi, from a shallow lake near Anderssen Point in Antarctica. They also proposed a new combination H. basiliensis (previously Pseudendoclonium basiliense). The genus Chamaetrichon was described by Tupa (1974). The type species C. capsulatum was found on the liverwort, Pallavicia lyelli submerged in a shallow drainage area of Double Lake in Sam Houston National Forest (Texas).

Our study revealed that the authentic strains of these taxa have a similar morphology and are phylogenetically very closely related. However, other strains assigned as Pseudendoclonium basiliense and Chamaetrichon capsulatum are not closely to these strains and were therefore described as new genera below. Unfortunately, the generic name Hazenia and its type species H. mirabilis was described in one diagnosis (descriptio generico-specifica, Art. 38.5, ICN) and no type was designated (Art. 40.1, ICN). The situation of the nomenclatural status is similar to those described above for Trichosarcina. The herbarium specimen of Hazenia deposited at Chicago Natural History Museum of this species was not indicated as type material (IRN 3565921, barcode C0172554F; Fieldmuseum.org). Therefore, this genus and species and all other proposed combinations are invalid. In contrast, the genus Chamaetrichon was validly published by designation of $C$. capsulatum as type species. As type for this species the culture DDT-8 (= UTEX 1918) 
was designated, which is not permitted by the ICN, but a dried specimen of DDT- 8 was deposited under the number IRN 3566414 (barcode C0500089F) at the Field Museum, Chicago. Therefore, this genus is valid and all taxa of this lineage belong to the genus Chamaetrichon. The necessary taxonomic changes are as follows.

Chamaetrichon Tupa 1974, Beih. Nova Hedwigia 46: 70-71 (diagnosis latina).

Synonym: Hazenia Bold 1958, Am. J. Bot. 45: 737-743 (nom. invalid).

Investigated strains: SAG 466-1, SAG 1.87, SAG 18.88, SAG 23.88, SAG 2396, UTEX 1918, ULVO-15 (Fig. 21).

Chamaetrichon basiliensis (Vischer) Darienko et Pröschold comb. nov. (Fig. 21A-F)

Basionym: Pseudendoclonium basiliense Vischer 1926: Bull. Soc. Bot. Gen. 18, ser. 2: 36-37, figs I-V, X-XI (iconotypus); non Pseudendoclonium basiliense var. brandii Vischer 1933, Hazenia basiliensis (Vischer) Skaloud, Nedbalová, Elster et Komárek 2013, Pol. Biol. 36: 1288 (comb. invalid).

Synonym: Chamaetrichon capsulatum Tupa 1974, Beih. Nova Hedwigia 46: 70-71, Hazenia mirabilis Bold 1958, Am. J. Bot. 45: 737-743 (nom. invalid), Hazenia broadyi Skaloud, Nedbalová, Elster et Komárek 2013, Pol. Biol. 36: 1288.

Lectotype (designated herein): Fig. 4 a-i in Vischer (1926).

Epitype (designated herein in support of the lectotype): The strain SAG 466-1 is permanently cryopreserved in a metabolically inactive state (cryopreserved in liquid nitrogen) in the SAG, University of Göttingen, Germany.

ITS-2 DNA Barcode: CHA1a/b/c in Figs S2.

Note: The strain ULVO-15 (see Fig. 21E), isolated from UK, Northamptonshire, Pitsford Water in England (Table S1), has been reported as closely corresponding to Helicodictyon planctonicum (John 2011) but is now identified as Chamaetrichon basiliensis based on our analyses.

Tupiella Darienko et Pröschold gen. nov.

Synonym: Pseudendoclonium Wille sensu Tupa p.p.

Diagnosis: The thallus from attached prostrate and short, erected filaments. Branching is abundant, and it occurs on one or both sides. Vegetative cells are cylindrical. The terminal cells of erected filaments are often tapered. Chloroplasts are parietal, massive, and contain pyrenoids. Vegetative cells are unicellular. Asexual reproduction occurs via zoospores and large akinetes. Zoospores are quadriflagellated. Akinetes are sphaerical with thick cell wall. Sexual reproduction is not observed.

This genus differs from the phylogenetically close related genus Sarcinofilum by absence of pluriserial filaments and by differences in SSU-ITS sequences.

Type species (designated herein): Tupiella speciosa Darienko et Pröschold sp. nov.

Investigated strains: CCALA 423, ULVO-11 (Fig. 22).

Tupiella speciosa Darienko et Pröschold sp. nov. (Fig. 22A-K)

Diagnosis: The thallus from the attached prostrate and short, erect filaments. Branching is rare and occurs on one or both sides. The terminal cells of erected filaments are often tapered or slightly pointed $(13.5 \times 6.0-17.5 \times 4.0 \mu \mathrm{m})$. Vegetative cells of young filaments are cylindrical with parietal chloroplasts containing a pyrenoid surrounded by two large starch grains and two large vacuoles, $(8.5 \times 4.0-12.5 \times 4.0 \mu \mathrm{m})$. Vegetative cells are unicellular. The prostrate filaments occur in the form of 8-16-cell packages. The filaments are easy disintegrated in unicells or 2-4-celled packages in old cultures and are 10-14.2 $\mu \mathrm{m}$ in diameter. Reproduction by zoospores is not observed. Mature culture start to produce large swollen cells, which swell to approximately $20 \mu \mathrm{m}$ in diameter, with chloroplasts, pyrenoids, and a strongly vacuolized cytoplasm; they possess a thick-layered cell wall without special ornamentation. The swollen cells start to grow up on one side up to long, thin filaments that become later branched or produce 2-4-cell packages. From those packages, short filaments (one per each cell) start to grow.

Type locality: Lednice n.M., Czech Republic.

Holotype (designated herein): The strain CCALA 423 is permanently cryopreserved in a metabolically inactive state (cryopreserved in liquid nitrogen) in the CCALA (Culture Collection of Autotrophic Organisms), Institute of Botany CAS, Czech Republic.

Iconotype (designated herein in support of the holotype): Fig. 22 in this study.

ITS-2 DNA Barcode: TUP1 in Figs S2. 


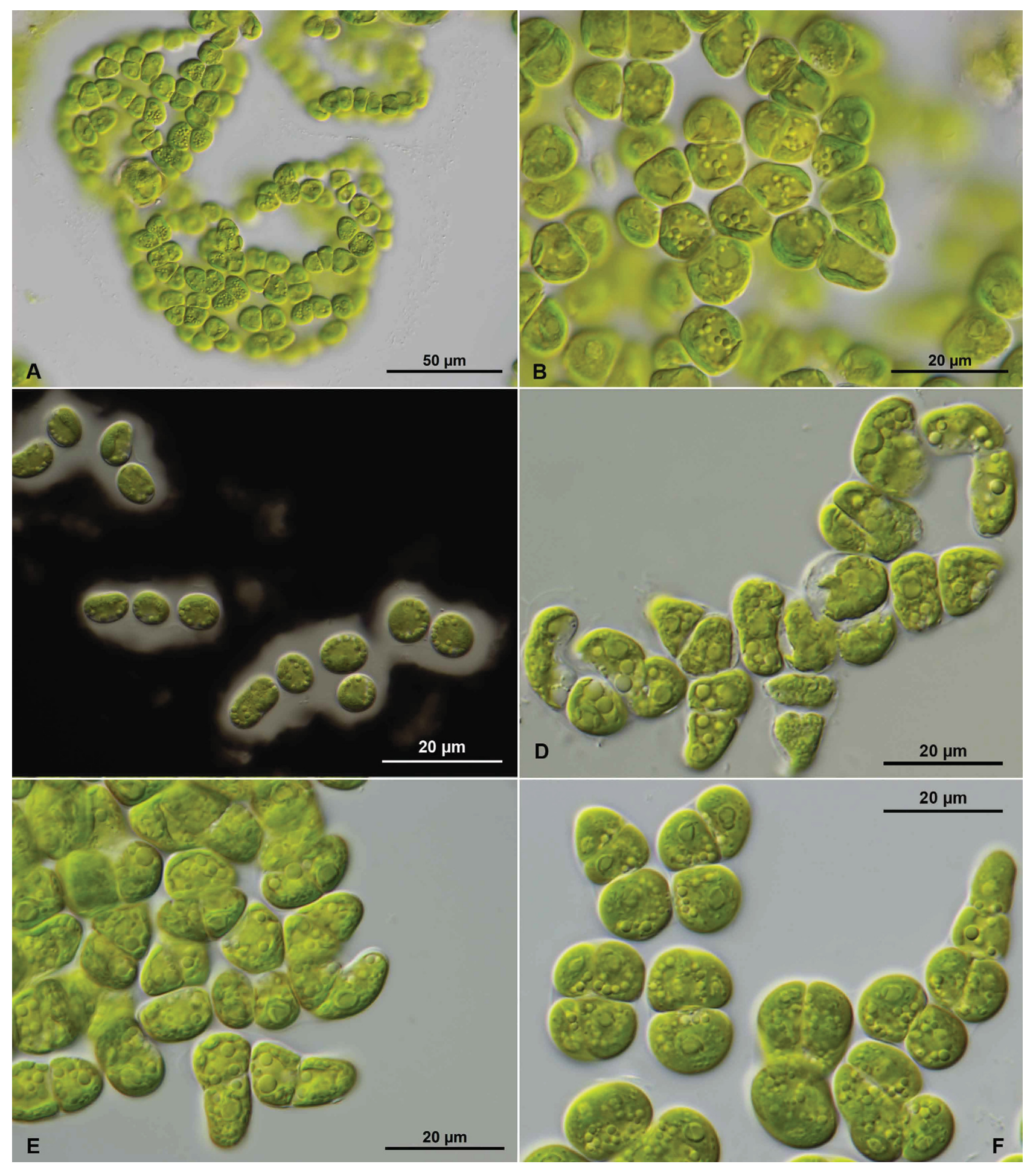

FIGURE 21. Overview about the morphology of the investigated Chamaetrichon strains grown on MIEB12 medium. A, B. SAG 1.87, general and close view of filaments, with a common mucilage, C. UTEX 1918, filaments with rudimentary branching, surrounded by common mucilage stained with indian ink, D. SAG 23.88, branched filaments, E. ULVO-15, short branched filaments surrounded by mucilage at the edge of the colony, F. SAG 2396, short filaments and packets, surrounded by common matrix.

Tupiella akineta (Tupa) Darienko et Pröschold comb. nov.

Basionym: Pseudendoclonium akinetum Tupa 1974, Beih. Nova Hedwigia 46: 64-65 (diagnosis latina), fig. 8; figs 114-129, 252, 280-282 (iconotypus). 


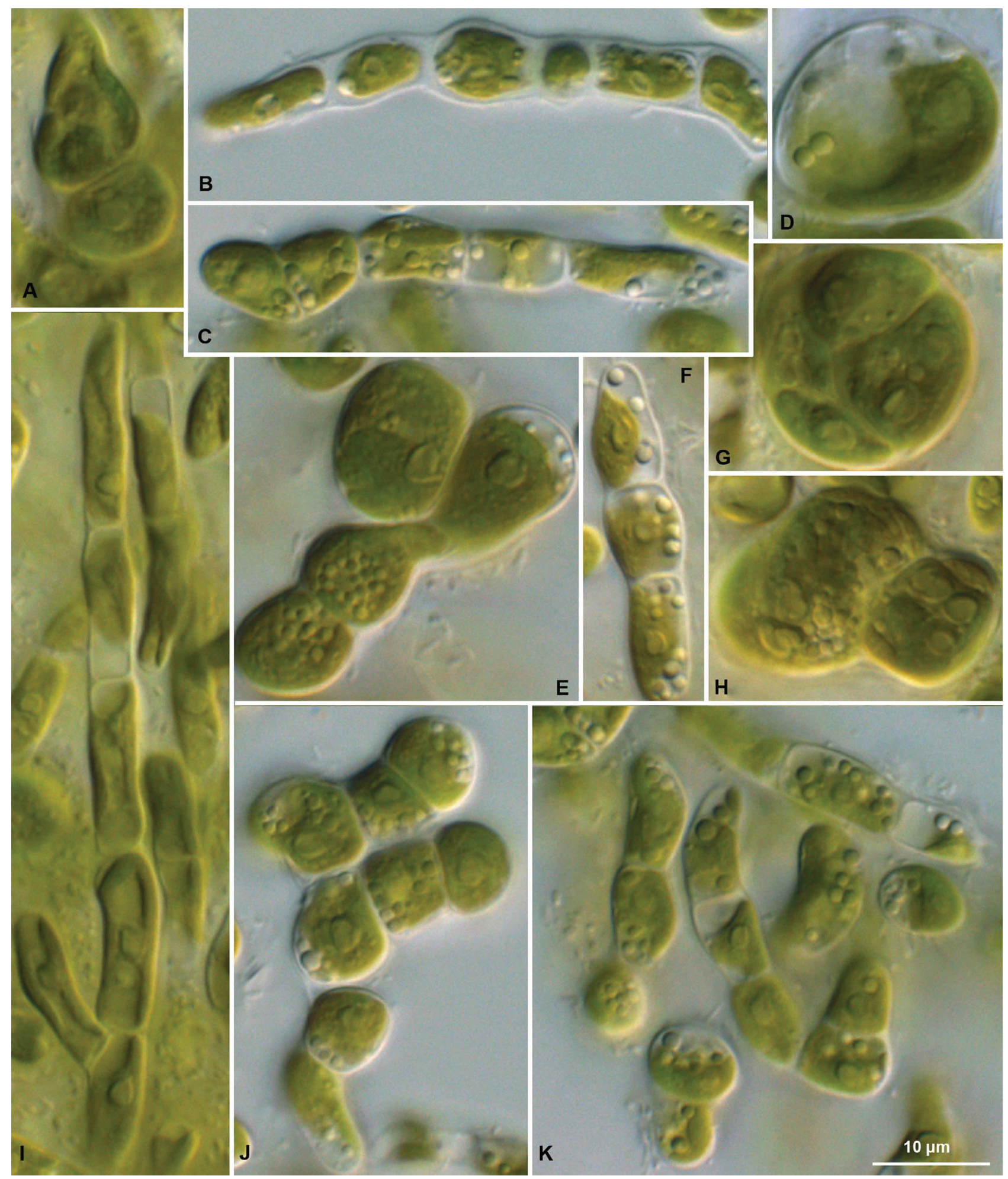

FIGURE 22. Morphology of Tupiella speciosa CCALA 423 grown on 3NBBM medium.

Vischerioclonium Darienko et Pröschold gen. nov.

Diagnosis: The young thallus consists of an abundance of long branched filaments. Vegetative cells of young filaments are square with parietal chloroplasts, a single pyrenoid and a nucleus. End cells are slightly tapered or slightly pointed. The later thallus starts to form irregular rich prostrate and erect filaments. The mature thallus consists mostly of prostrate pluriserial filaments that easy disintegrate into cell packages, which form a short uniserial part consisting of several cells only at the ends. Vegetative cells in pluriserial filaments are rounded. Reproduction occurs via zoospores, akinetes and disintegrating filaments. Akinetes have thick cell wall without special ornamentation. Zoospore are quadriflagellated and lack a cell wall. Sexual reproduction is not observed. 
Type species (designated herein): Vischerioclonium submersum Darienko et Pröschold sp. nov.

Investigated strains: UTEX 1913 (Fig. 23).

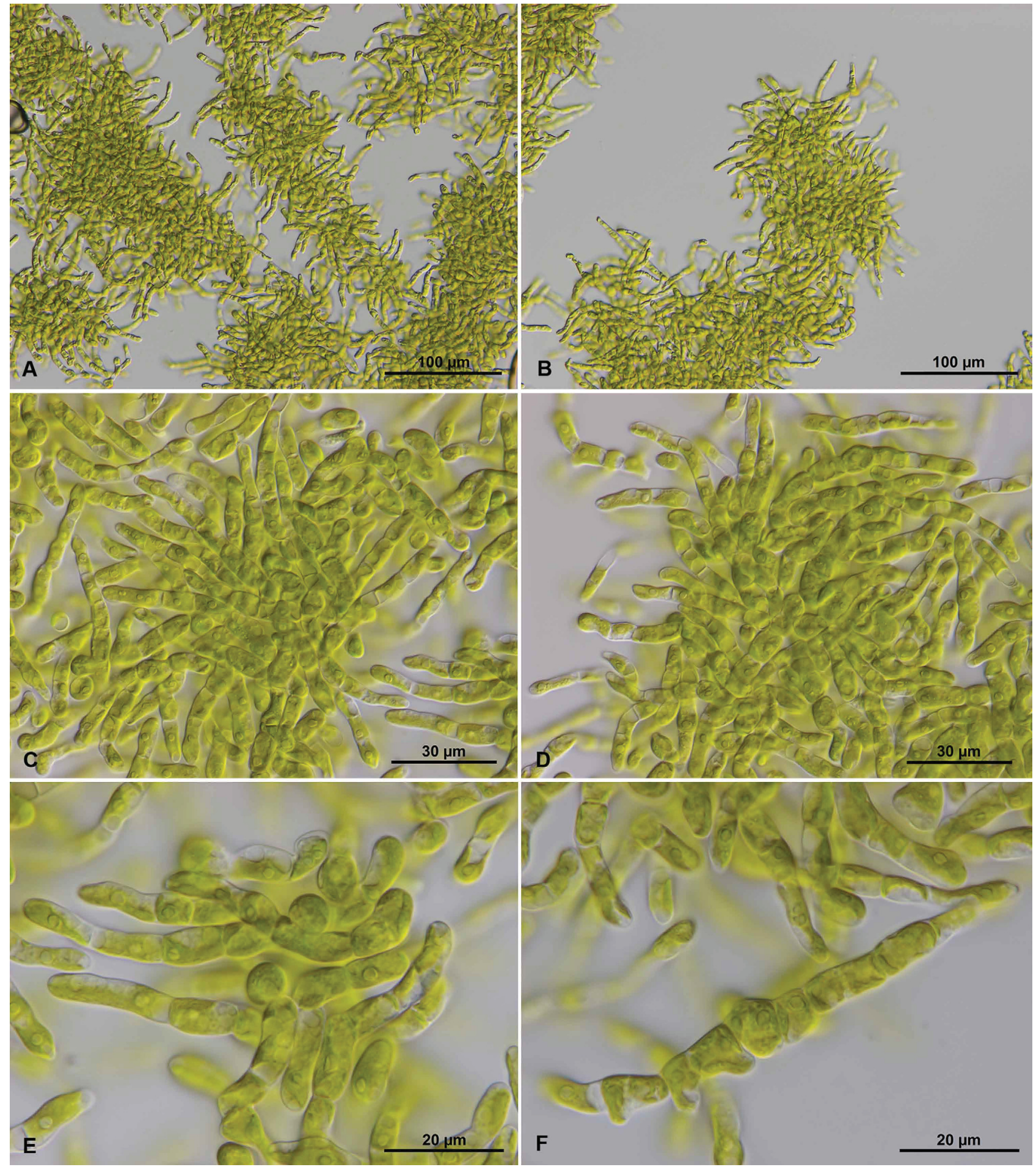

FIGURE 23. Morphology of Vischerioclonium submersum UTEX 1913 grown on 3NBBM medium.

Vischerioclonium submersum Darienko et Pröschold sp. nov. (Fig. 23A-F)

Synonym: Pseudendoclonium basiliense var. brandii sensu Tupa 1974, non Pseudendoclonium basiliense var. brandii sensu Vischer 1933.

Diagnosis: (after Tupa 1974) Thalli are small, 100-200 (up to 300) $\mu \mathrm{m}$ in diameter, and branched. The thallus consists of prostrate and erected systems of filaments. Branches of erected system consist 5-15 cells. Young cells are 4.0-5.0 $\mu \mathrm{m}$ wide $\times 10.0-20.0 \mu \mathrm{m}$ long. Terminal cells can reach up to $30 \mu \mathrm{m}$ and are tapered. Vegetative cells are uninucleate and contain parietal chloroplasts with a pyrenoid surrounded by starch grains. Old cells are barrel-shaped to spherical, 8.0-10.0 $\mu \mathrm{m}$ in diameter. Erected filaments in old culture become pluriseriate or form packet-like structures. 
Reproduction occurs via zoospores and akinetes, or by thallus fragmentation. Zoospores are $6.0-7.0 \mu \mathrm{m} \times 3.5-4.5$ $\mu \mathrm{m}$, have an anterior stigma and cell nucleus, and are quadriflagellated. Zoosporangia are 6.0-12 $\mu \mathrm{m}$ in diameter and usually contain 4-8 daughter cells. Akinetes reach $20 \mu \mathrm{m}$ in diameter. Sexual reproduction is not observed.

Holotype (designated herein): The strain UTEX 1913 is permanently cryopreserved in a metabolically inactive state (cryopreserved in liquid nitrogen) in the SAG, University of Göttingen, Germany.

Iconotype (designated herein in support of the holotype): Fig. 110 in Tupa (1974).

ITS-2 DNA Barcode: VIS1 in Figs S2.

\section{Acknowledgement}

The authors wish to thank Maike Lorenz and Thomas Friedl for supporting this work and the culture collections SAG, CCAP, and CCALA as well as Alena Lukešová, Nicole Pietrasiak and Akira Peters for providing of the investigated strains. We are also very grateful to Richard Moe, Michael Guiry and Kanchi Gandhi for their help by nomenclatural questions. The Open Access was funded by the Leopold-Franzens-University of Innsbruck.

\section{References}

Akaike, H. (1974) A new look at the statistical model identification. IEEE Transactions on Automatic Control 19: 716-723. https://doi.org/10.1109/TAC.1974.1100705

Biebel, P. (1968) Reproduction in Helicodictyon planctonicum (Whitford) Whitford and Schumacher. Journal of Phycology 4: 55-58. https://doi.org/10.1111/j.1529-8817.1968.tb04676.x

Binz, A \& Vischer, W. (1956) Zur Flora des Rheinlaufes bei Basel.I. Verhandlungen der Naturforschenden Gesellschaft in Basel 67: $195-200$

Blinn, D.W. \& Stein, J.R. (1970) Distribution and taxonomic reappraisal of Ctenocladus (Chlorophyceae, Chaetophorales). Journal of Phycology 6: 101-105.

https://doi.org/10.1111/j.1529-8817.1970.tb02365.x

Bold, H. (1958) Three new chlorophycean algae. American Journal of Botany 45: 737-743. https://doi.org/10.2307/2439733

Borzi, A. (1883) Saggio di ricerche Sulla biologia delle alghe. Ctenocladus, gen. nov. Studi Algologici 1: 27-50.

Bourrelly, P. (1966) Les Algues d'Eau Douce I. Les Algues Vertes. Boubée, Paris, 511 pp.

Bourrelly (1990) Les Algues d'Eau Douce I. Les Algues Vertes, Reimpression revue et augmentée. Boubée, Paris, 572 pp.

Broady, P. (1982) New records of chlorophycean microalgae cultures from Antarctic terrestrial habitats. Nova Hedwigia 36: $445-484$.

Broady, P.A. \& Ingerfeld, M. (1993) Three new species and a new record of chaetophoracean (Chlorophyta) algae from terrestrial habitats in Antarctica. European Journal of Phycology 28: 25-31. https://doi.org/10.1080/09670269300650041

Coleman, A.W. (2000) The significance of a coincidence between evolutionary landmarks found in mating affinity and a DNA sequence. Protist 151: 1-9. https://doi.org/10.1078/1434-4610-00002

Coleman, A.W. (2003) ITS2 is a double-edged tool for eukaryote evolutionary comparisons. Trends in Genetics 19: 370-375. https://doi.org/10.1016/S0168-9525(03)00118-5

Coleman, A.W. (2009) Is there a molecular key to the level of biological species in eukaryotes? A DNA guide. Molecular Phylogenetics and Evolution 50: 197-203. https://doi.org/10.1016/j.ympev.2008.10.008

Cote, C.A., Greer, C.L. \& Peculis, B.A. (2002) Dynamic conformational model for the role of ITS2 in pre-rRNA processing in yeast. $R N A$ 8: 786-797. https://doi.org/10.1017/S1355838202023063

Chappell, D.F. \& O‘Kelly, C.J. (1991) Ultrastructure and taxonomy of the Antarctic terrestrial algae Trichosarcina mucosa (Broady) comb. nov. (Ulotrichales, Chlorophyta). Cryptogamic Botany 2/3: 252-257.

Dangeard, P. (1965) Sur cinq espèces d' Ulvella. Le Botaniste 48: 45-64.

Dangeard, P.A. (1911) Un nouveau genre d'algues. Bulletin de la Société Botanique de France 58: 309-311. https://doi.org/10.1080/00378941.1911.10832323 
Dangeard, P.A. (1912) Recherches sur quelques algues nouvelles on peu connues. Le Botaniste 12: 1-22.

Darienko, T., Friedl, T. \& Pröschold, T. (2009) Desmochloris mollenhaueri - a new terrestrial ulvophycean alga from south-west African soils. (Molecular phylogeny and systematics of terrestrial Ulvophyceae I.). Algological Studies 129: 25-40. https://doi.org/10.1127/1864-1318/2009/0129-0025

Darienko, T., Gustavs, L., Eggert, A., Wolf, W. \& Pröschold, T. (2015) Evaluating the species boundaries of green microalgae (Coccomyxa, Trebouxiophyceae, Chlorophyta) using integrative taxonomy and DNA barcoding with further implications for the species identification in environmental samples. PLOS One 10: e127838. https://doi.org/10.1371/journal.pone.0127838

Darienko, T., Gustavs, L. \& Pröschold, T. (2016) Species concept and nomenclatural changes within the genera Elliptochloris and Pseudochlorella (Trebouxiophyceae) based on an integrative approach. Journal of Phycology 52: 1125-1145. https://doi.org/10.1111/jpy.12481

Darty, K., Denise, A. \& Ponty, Y. (2009) VARNA: Interactive drawing and editing of the RNA secondary structure. Bioinformatics 25: 1974-1975. https://doi.org/10.1093/bioinformatics/btp250

Demchenko, E., Mikhailyuk, T., Coleman, A.W. \& Pröschold, T. (2012) Generic and species concepts in Microglena (previously the Chlamydomonas monadina group) revised using an integrative approach. European Journal of Phycology 47: 264-290. https://doi.org/10.1080/09670262.2012.678388

Do, C.B., Woods, D.A. \& Batzoglou, S. (2006) CONTRAfold: RNA secondary structure prediction without physics-based models. Bioinformatics 22: e90-e98. https://doi.org/10.1093/bioinformatics/bt1246

Dodel A. (1876) Die Kraushaar-Alge, Ulothrix zonata. Ihre geschlechtliche und ungeschlechtliche Fortpflanzung. Wilhelm Engelmann, Leipzig, 144 pp.

Eliaš, M. \& Neustupa, J. (2009) Pseudomarvania gen. nov. (Chlorophyta, Trebouxiophyceae), a genus for "budding" subaerial green algae Marvania aerophytica Neustupa et Sejnohova and Stichococcus ampulliformis Handa. Fottea 9: 169-177. https://doi.org/10.5507/fot.2009.017

Ettl, H. \& Gärtner, G. (1995) Syllabus der Boden-, Luft- und Flechtenalgen. Stuttgart, Jena and Heidelberg: Gustav Fischer, 721 pp.

Ettl, H. \& Gärtner, G. (2014) Syllabus der Boden-, Luft- und Flechtenalgen. Berlin and Heidelberg: Springer, 773 pp. https://doi.org/10.1007/978-3-642-39462-1

Friedl, T. (1996) Evolution and the polyphyletic genus Pleurastrum (Chlorophyta): inferences from nuclear-encoded ribosomal DNA sequences and motile cell ultrastructure. Phycologia 35: 456-469. https://doi.org/10.2216/i0031-8884-35-5-456.1

Friedl, T. \& O'Kelly C.J. (2002) Phylogenetic relationship of green algae assigned to the genus Planophila (Chlorophyta): evidence from 18S rDNA sequence data and ultrastructure. European Journal of Phycology 37: 373-384. https://doi.org/10.1017/S0967026202003712

Gayral, P. \& Lepailleur, H. (1967) Une rare Chlorophycee unicellulaire marine: Heterogonium salinium Dangeard. Revue Algologique, Nouvelle Série 9: 131-134.

Geitler, L. (1942) Zur Kenntnis der Bewohner des Oberflächenhäutchens einheimischer Gewässer. Biologia Generalis 16: $450-475$.

Gerneck, R. (1907) Zur Kenntnis der niederen Chlorophyceen. Beihefte zum Botanischen Centralblatt 21/II: 221-290.

Gibson, A., Gowri-Shankar, V., Higgs, P. \& Rattray, M. (2005) A comprehensive analysis of mammalian mitochondrial genome base composition and improved phylogenetic methods. Molecular Biology and Evolution 22: 251-264. https://doi.org/10.1093/molbev/msi012

Groover, R.D. \& Bold, H.C. (1969) Phycological Studies. VIII. The taxonomy and comparative physiology of the Chlorosarcinales and certain other edaphic algae. University of Texas Publications 6907: 1-165.

Groover, R.D. \& Hofstetter, A.M. (1969) Planophila terrestris, a new green algae from Tennessee soil. Tulane Studies in Zoology and Botany 15: 75-80.

Guillard, R.R.L., Bold, H.C. \& MacEntee, F.J. (1975) Four new unicellular chlorophyceaen algae from mixosaline habitats. Phycologia 14: $13-24$. https://doi.org/10.2216/i0031-8884-14-1-13.1

Hallmann, C., Stannek, L., Fritzlar, D., Hause-Reitner, D., Friedl, T. \& Hoppert, M. (2013) Molecular diversity of phototrophic biofilms on building stone. FEMS Microbiol. Ecol. 84: 355-372. https://doi.org/10.1111/1574-6941.12065

Herbst, D.B. \& Castenholz, R.W. (1994) Growth of the filamentous green alga Ctenocladus circinnatus (Chaetophorales, Chlorophyceae) in relation to environmental salinity. Journal of Phycology 30: 588-593. https://doi.org/10.1111/j.0022-3646.1994.00588.x 
Higgs, P., Jameson, D., Jow, H. \& Rattray M. (2003) The evolution of tRNA-Leu genes in animal mitochondrial genomes. Journal of Molecular Evolution 57: 435-445. https://doi.org/10.1007/s00239-003-2494-6

Hoffmann, L. \& Darienko, T. (2010): Subaerial algae and cyanobacteria from the archaeological remains of Carthage (Tunisia), including the record of a species of Cyanidium (Rhodophyta). Algological Studies 135: 41-60. https://doi.org/10.1127/1864-1318/2010/0135-0041

Hudelot, C., Gowri-Shankar, V., Jow, H., Rattray, M. \& Higgs, P. (2003) RNA-based phylogenetic methods: application to mammalian mitochondrial RNA sequences. Molecular Phylogenetics and Evolution 28: 241-252. https://doi.org/10.1016/S1055-7903(03)00061-7

Huelsenbeck, J.P. \& Ronquist, F. (2001) MRBAYES: Bayesian inference of phylogeny. Bioinformatics 17: 754-755. https://doi.org/10.1093/bioinformatics/17.8.754

Iyengar, M.O.P. \& Philipose, M.T. (1956) Gloeotilopsis planctonica gen. et sp. nov., a new member of the Ulotrichaceae. Journal of the Indian Botanical Society 35: 365-370.

John, D.M. (2011) Orders Chaetophorales, Microsporales, Ulotrichales. In: John, D.M., Whitton, B.A. \& Brook, A.J. (Eds.) The freshwater algal flora of the British Isles. Cambridge University Press, Cambridge, UK, pp. 524-554.

John, D.M. \& Johnson, L.R. (1989) A cultural assessment of the freshwater species of Pseudendoclonium Wille (Ulotrichales, Ulvophyceae, Chlorophyta). Archiv für Hydrobiologie, Supplement 82, Algological Studies 54: 79-112.

Johnson, L.R. \& John, D.M. (1990) Observation on Dilabifilum (class Chlorophyta, order Chaetophorales sensu stricto) and allied genera. British Phycological Journal 25: 53-61. https://doi.org/10.1080/00071619000650051

Jow, H., Hudelot, C., Rattray, M. \& Higgs, P. (2002) Bayesian phylogenetics using an RNA substitution model applied to early mammalian evolution. Molecular Biology and Evolution 19: 1591-1601. https://doi.org/10.1093/oxfordjournals.molbev.a004221

Kornmann, P. (1973) Codiolophyceae, a new class of Chlorophyta. Helgoländer wissenschaftliche Meeresuntersuchungen 25: 1-13. https://doi.org/10.1007/BF01609956

Kornmann, P. \& Sahling, P.-H. (1983) Meeresalgen von Helgoland: Ergänzung. Helgoländer Meeresuntersuchungen 36: 1-65. https://doi.org/10.1007/BF01995795

Liu, B., Liu, X., Hu, Z., Zhu, H. \& Liu, G. (2016) Phylogenetic position and morphological observation of the Ctenocladus circinnatus Borzi, a rare green alga from Changtang Plateau, China. Phytotaxa 260: 75-82. https://doi.org/10.11646/phytotaxa.260.1.8

Lorenz, R. Bernhart, S., Höner zu Siederdissen, C., Tafer, H., Flamm, C., Stadler, P.F. \& Hofacker, I.L. (2011) ViennaRNA Package 2.0. Algorithms for Molecular Biology 6: 26. https://doi.org/10.1186/1748-7188-6-26

Lukešová, A. (1991) Three filamentous green algae isolated from soil. Archiv für Protistenkunde 139: 69-83. https://doi.org/10.1016/S0003-9365(11)80009-6

Mai, J.C. \& Coleman, A.W. (1997) The internal transcribed spacer 2 exhibits a common secondary structure in green algae and flowering plants. Journal of Molecular Evolution 44: 258-271.

https://doi.org/10.1007/PL00006143

Marin, B., Palm, A., Klingberg, M. \& Melkonian, M. (2003) Phylogeny and taxonomic revision of plastid-containing euglenophytes based on SSU rDNA sequence comparisons and synapomorphic signatures in the SSU rRNA secondary structure. Protist 154: 99-145. https://doi.org/10.1078/143446103764928521

Mattox, K.R. \& Stewart, K.D. (1984) Classification of green algae: a concept based on comparative cytology. In: Irvine, D.E.G. \& John, D.M. (Eds.) The Systematics of Green Algae. The Systematics Association Special Volume 27. Academic Press, London, UK, pp. $29-72$.

Mullins, R.F. (2007) A molecular phylogenetic assessment of Pseudendoclonium. Master Thesis, University of Massachusetts, Amherst, USA.

Nichols, H.W. \& Bold, H.C. (1965) Trichosarcina polymorpha gen. et sp. nov. Journal of Phycology 1: 34-38. https://doi.org/10.1111/j.1529-8817.1965.tb04552.x

Novichkova-Ivanova, L.N. (1984) Pochvennye vodorosli fitocenozov Saharo-Gobiyskoy pustynnoy oblasti (Soil Algae of Phytocoenoses of the Sahara-Gobi Desert Area). Leningrad, Nauka, 256 pp. [in Russian]

O‘Kelly, C.J. \& Floyd, G.L. (1984) Correlations among patterns of sporangial structure and development, life histories, and ultrastructural features in the Ulvophyceae. In: Irvine, D.E.G. \& John, D.M. (Eds.) The Systematics of Green Algae. The Systematics Association Special Volume 27. Academic Press, London, UK, pp. 121-156.

Pascher, A. (1939) Heterokonten. In: Rabenhorst, L. (Ed.) Kryptogamen-Flora Deutschlands, Österreichs und der Schweiz, Band 11, 
Leipzig, 1092 pp.

Pascher, A. (1944) Über Conidien-artige Sporen bei grünen Algen. Beiheften zum Botanischen Centralblatt 57/A: 360-375.

Posada, D. (2008) jModelTest: phylogenetic model averaging. Molecular Biology and Evolution 25: 1253-1256. https://doi.org/10.1093/molbev/msn083

Presl, C.B. (1851) Epimeliae Botanicae. A. Haase, Prague, 264 pp.

Printz, H. (1927) Chlorophyceae. In: Engler, A. (Ed.) Die Natürliche Pflanzenfamilien 3. Leipzig, Engelmann, 255 pp.

Printz , H. (1964) Die Chaetophoralen der Binnengewässer. Hydrobiologia 24: 1-376. https://doi.org/10.1007/BF00170411

Pröschold, P. \& Leilaert, F. (2007) Systematics of the green algae: Conflict of classic and modern approaches. In: Brodie, J. \& Lewis, J. (Eds.) Unravelling the Algae: The Past, Present, and Future of the Algae Systematics. Taylor and Francis 2007, pp. 123-153.

Reisigl, H. (1964) Zur Systematik und Ökologie alpiner Bodenalgen. Österreichische Botanische Zeitschrift 111: $402-499$. https://doi.org/10.1007/BF01372910

Ronquist, F. \& Huelsenbeck, J.P. (2003) MRBAYES 3: Bayesian phylogenetic inference under mixed models. Bioinformatics 19: 15721574.

https://doi.org/10.1093/bioinformatics/btg180

Ruinen, J. (1933) Life cycle and environment of Lochmiopsis sibirica Woron. Recueil des Travaux Botaniques Neerlandais 30: 1-73.

Schlösser, U.G. (1994) SAG-Sammlung von Algenkulturen at the University of Göttingen. Botanica Acta 107: 424-429. http://dx.doi.org/10.1111/j.1438-8677.1994.tb00784.x

Schlösser, U.G. (1997) Additions to the culture collections of algae since 1994. Botanica Acta 110: 424-429. https://doi.org/10.1111/j.1438-8677.1997.tb00659.x

Skaloud, P., Nedbalová, L., Elster, J. \& Komárek, J. (2013a) A curious occurrence of Hazenia broadyi spec. nova in Antarctic and review of genus Hazenia (Ulotrichales, Chlorophyceae). Polar Biology 36: 1281-1291. https://doi.org/10.1007/s00300-013-1347-z

Skaloud, P., Kalina, T., Nemjová, De Clerck, O. \& Leliaert (2013b) Morphology and phylogenetic position of the freshwater green microalgae Chlorochytrium (Chlorophyceae) and Scotinosphaera (Scotinosphaerales, ord. nov., Ulvophyceae). Journal of Phycology 49: $115-129$. https://doi.org/10.1111/jpy.12021

Sluiman, H. (1989) The green algal class Ulvophyceae - an ultrastructural survey and classification. Cryptogamic Botany 1: 83-94.

Sluiman, H. (1991) Cell division in Gloeotilopsis planctonica, a newly identified ulvophycean alga (Chlorophyta) studied by freeze fixation and freeze substitution. Journal of Phycology 27: 291-298.

https://doi.org/10.1111/j.0022-3646.1991.00291.x

Smith, G.M. (1950) Fresh-water algae of United States. McGraw-Hill, New York, London, 719 pp.

Snow, J. (1899) Pseudo-Pleurococcus, nov. gen. Annals of Botany 13: 189-195. https://doi.org/10.1093/oxfordjournals.aob.a088729

Snow, J. (1911) Two epiphytic algae. Botanical Gazette 51: 360-368. https://doi.org/10.1086/330525

Snow (1912) Two epiphytic algae: A correction. Botanical Gazette 53: 347. https://doi.org/10.1086/330810

Stamatakis, A. (2006) RAxML-VI-HPC: maximum likelihood-based phylogenetic analyses with thousands of taxa and mixed models. Bioinformatics 22: 2688-2690. https://doi.org/10.1093/bioinformatics/btl446

Starmach, K. (1972) Flora Slodkowodna Polski: Chlorophyta III. Zielenice nitkowate. Polska Akademia Nauk Instytut Botaniki, Krakow, 755 pp. [in Polish]

Swofford, D.L. (2002) PAUP* Phylogenetic Analysis Using Parsimony (*and Other Methods), Version 4.0b10. Sunderland, MA, USA: Sinauer Associates.

Telford, M.J., Wise, M.J. \& Gowri-Shankar, V. (2005) Consideration of RNA secondary structure significantly improves likelihood-based estimates of phylogeny: examples from the bilateria. Molecular Biology and Evolution 22: 1129-1136. https://doi.org/10.1093/molbev/msi099

Thüs, H., Muggia, L., Pérez-Ortega, S. Favero-Longo, S. E., Joneson, S., O’Brien, H., Nelsen, M.P., Duque-Thüs, R., Grube, M., Friedl, T., Brodie, J., Andrew, C.J., Lücking, R., Lutzoni, F. \& Gueidan, C. (2011) Revisiting photobiont diversity in the lichen family Verrucariaceae (Ascomycota). European Journal of Phycology 46: 399-415. https://doi.org/10.1080/09670262.2011.629788

Thompson, R.H. \& Wujek, D.E. (1996) The identity of Filoprotococcus and Trichosarcina (Chlorophyta) in Kansas. Transactions of the Kansas Academy of Science 99: 152-156. 
https://doi.org/10.2307/3627988

Tschermak-Woess, E. (1970) Über wenig bekannte und neue Flechtengonidien V. Der Phycobiont von Verrucaria aquatilis und Fortpflanzung von Pseudopleurococcus arthopyreniae. Österreichische Botanische Zeitung 118: 443-455.

https://doi.org/10.1007/BF01376256

Tupa, D.D. (1974) An investigation of certain chaetophoralean algae. Beihefte zur Nova Hedwigia 46: 1-155.

Vischer, W. (1926) Etudes d'Algologie experiméntale. Bulletin de la Société Botanique de Genève (Serié 2) 18: 1-85.

Vischer, W. (1933) Über einige kritische Gattungen und die Systematik der Chaetophorales. Beihefte zum Botanischen Centralblatt 51/I: $1-100$.

Vischer, W. (1953) Über primitive Landpflanzen. Berichte der Schweizerischen Botanischen Gesellschaft 63: 169-193.

Vischer (1956) Zur Flora des Rheinlaufes bei Basel. II. Verhandlungen der Naturforschenden Gesellschaft in Basel 67: $200-217$.

Woronichin, N.N. \& Popova, T.G. (1929) Lochmiopsis a new genus of algae from Fam. Leptosiraceae. Izdanie Tomskogo Otdeleniya Russkogo Botanicheskogo Obshchestva 3: 1-9.

Watanabe, S., Kuroda, N. \& Maiwa, F. (2001) Phylogenetic status of Helicodictyon planctonicum and Desmochloris halophila gen. et comb. nov. and the definition of the class Ulvophyceae (Chlorophyta). Phycologia 40: 421-434.

https://doi.org/10.2216/i0031-8884-40-5-421.1

Watanabe, S. (2002) Erratum. Phycologia 41: 672.

Watanabe, S. \& Nakayama, T. (2007) Ultrastructure and phylogenetic relationships of the unicellular green algae Ignatius tetrasporus and Pseudocharacium americanum (Chlorophyta). Phycological Research 55: 1-16.

https://doi.org/10.1111/j.1440-1835.2006.00439.x

Wetherbee, R. \& Verbruggen, H. (2016) Kraftionema allantoides, a new genus and family of Ulotrichales (Chlorophyta) adapted for survival in the high intertidal pools. Journal of Phycology 52: 704-715.

https://doi.org/10.1111/jpy.12447

Whitford, L.A. (1956) Additions to the fresh-water algae in North Carolina I. Transactions of the American Microbiological Society 75 : 196-203.

https://doi.org/10.2307/3224008

Whitford, L.A. (1960) Helicodictyon planctonicum (Whitford) and Chlorosaccus fluidus Luther further note and corrections. Transactions of the American Microbiological Society 79: 227-229.

https://doi.org/10.2307/3224089

Whitford, L.A. \& Schumacher, G.J. (1966) Helicodictyon nom. nov. pro Heterodictyon and Helicodictyaceae fam. nov. (Ulotrichales). Phycologia 5: 274-276.

https://doi.org/10.2216/i0031-8884-5-4-274.1

Wille, N. (1901) Studien über Chlorophyceen I-VII. Skrifter udgivne af Videnskabsselskabet i Christiania. Mathematisk-Naturvidenskaelig Klasse 6: 1-46.

Wynne, M.J. \& Furnari, G. (2014) A census of J.P.L. Dangeard's invalid taxa with proposal to resolve the nomenclatural problems of some of them. Nova Hedwigia 98: 515-527. https://doi.org/10.1127/0029-5035/2014/0169

Yamamoto, M., Nishikawa, T., Kajitani, H. \& Kawano, S. (2007) Patterns of sexual reproduction in Nannochloris bacillaris and Marvania geminata (Chlorophyta, Trebouxiophyceae). Planta 226: 917-927.

https://doi.org/10.1007/s00425-007-0538-7

Zuker, M. (2003) Mfold web server for nucleic acid folding and hybridization prediction. Nucleic Acid Research 31: 3406-3615. https://doi.org/10.1093/nar/gkg595

\section{Supplemental material}

FIGURE S1. SSU rRNA secondary structure model of Ulothrix zonata (SAG 38.86).

FIGURES S2. ITS-2 secondary structures of the genera investigated genera. The structure shown represents the type species of each genus. The barcode region are marked in black circles in the structure. The barcode region were translated into a number code as described in Material \& Methods and is provided for each strain in the box below the structure. The changes (CBCs, HCBCs and insertions/deletions) are marked with an asterisk under the barcodes.

TABLE S1. Strains used in this study. Accession numbers new in this study are marked in bold. 